\title{
Soil contribution to carbon budget of Russian forests
}

L. Mukhortova (1,*, e-mail: l.mukhortova@gmail.com), D. Schepaschenko (2,3, e-mail: schepd@iiasa.ac.at), A Shvidenko (2,1, e-mail: shvidenk@iiasa.ac.at), I. McCallum (2, email: mccallum@iiasa.ac.at), F. Kraxner (2, e-mail: kraxner@iiasa.ac.at)

(1) V.N. Sukachev Institute of Forest, Siberian Branch of the Russian Academy of Science, Academgorodok 50(28), 660036 Krasnoyarsk, Russia.

(2) International Institute for Applied Systems Analysis, A-2361 Laxenburg, Austria.

(3) Moscow State Forest University, 141005 Mytischi, Moscow reg., Russia

(*) Corresponding author. Address: Akademgorodok 50(28), 660036 Krasnoyarsk, Russia. E-mail: 1.mukhortova@gmail.com

\begin{abstract}
The flux of $\mathrm{CO}_{2}$ from the soil to the atmosphere - soil respiration ( $\left.\mathrm{R}_{\mathrm{S}}\right)$, is one of the least known components of the terrestrial carbon cycle. $\mathrm{R}_{\mathrm{S}}$ depends on many factors and varies substantially in time and space. High uncertainty of $\mathrm{R}_{\mathrm{S}}$ flux valuation leads to a wide range of reported carbon budget estimates for Russian forests. We developed a modeling system for assessing soil carbon stock and heterotrophic soil respiration based on a possible maximum of relevant input indicators. The most comprehensive databases of $\mathrm{R}_{\mathrm{S}}$ in situ measurements focused on Northern Eurasia (780 records for the region) has been used. A statistical model for assessing Rs of Russian forests and its separation in autotrophic and heterotrophic parts were elaborated based on in situ measurements, climate parameters, soil and land cover datasets. The spatial resolution of the model is $1 \mathrm{~km}^{2}$. Russian forest soil accumulated 144.5 Pg C (or $17.6 \mathrm{~kg} \mathrm{C} \mathrm{m}^{-2}$ ) in $1 \mathrm{~m}$ depth, including $8.3 \mathrm{Pg} \mathrm{C}$ (or $1.0 \mathrm{~kg} \mathrm{C} \mathrm{m}^{-2}$ ) in the labile topsoil organic layer. The total heterotrophic soil respiration $\left(\mathrm{R}_{\mathrm{H}}\right)$ flux for the Russian forest is

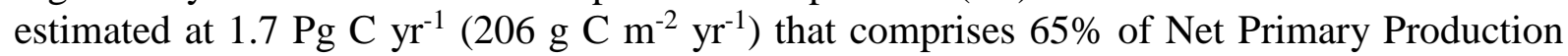
(NPP) and together with NPP is one of two major components of the net ecosystem carbon

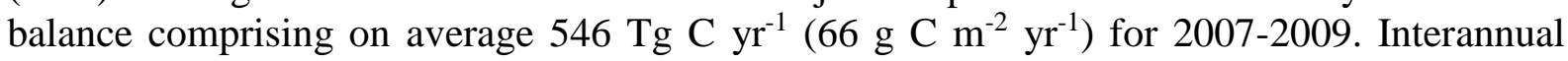
variability or $\mathrm{R}_{\mathrm{H}}$ in $1996-2005$ was estimated at $4.1 \%$ for forests of the whole country and typically from $5-11 \%$ for large individual regions with an average linear trend $+0.2 \%$ per year. The uncertainty of annual average of $\mathrm{R}_{\mathrm{H}}$ was estimated at $8 \%$ (confidential interval 0.9 ).
\end{abstract}

Keywords: carbon budget, soil respiration, soil organic carbon, Russia, forest

\section{Introduction}

Forests play an important role in the carbon (C) cycle and carbon sequestration at both regional and global scales. They represent the largest terrestrial ecosystem containing about 1150 Pg of organic carbon in live biomass, plant detritus and soil organic matter (Dixon et al., 1994). Whether forest is a source or sink of carbon to the atmosphere largely depends on the ratio between photosynthetic immobilization and respiratory release of $\mathrm{CO}_{2}$ and on various disturbances (Malhi et al., 1999).

Soil is recognized as the largest terrestrial carbon reservoir in the global carbon cycle (Janzen, 2005). Depending on soil type, tree species and the impacts of disturbances, soil can contribute up to $96 \%$ of the total carbon stock in forest ecosystems (Rumpel \& KögelKnabner, 2011; Mukhortova, 2012). Soil can accumulate or release carbon depending on 
climatic conditions, disturbance type and level, soil characteristics, and vegetation type. Each soil type has its own carbon carrying capacity - an equilibrium carbon content that depends on the soil properties, vegetation type and hydrothermal conditions (Guo \& Gifford, 2002). This equilibrium $\mathrm{C}$ content is the outcome of a balance between input and output fluxes to the pool of soil C (Fearnside \& Barbosa, 1998, Guo \& Gifford, 2002). The main source of organic matter input into the soil is vegetation and the amount of this input depends on ecosystems' productivity. The output flux includes mineralization of organic matter, losses due to disturbances and leaching of dissolved organic carbon from the ecosystem (Guo \& Gifford, 2002).

The mineralization efflux of $\mathrm{CO}_{2}$ from the soil surface (soil respiration - $\mathrm{RS}$ ) is a key component of the carbon cycle of terrestrial ecosystems, which can contribute $50-95 \%$ of total ecosystem respiration (e.g. Xu \& Qi, 2001). $\mathrm{R}_{\mathrm{S}}$ is the sum of such processes as autotrophic root respiration $\left(\mathrm{R}_{\mathrm{A}}\right)$ and plant residues decomposition (respiration of heterotrophic organisms). It can vary significantly across both time and space according to changes in vegetation and soil properties (e.g. Rochette et al., 1991; Stoyan et al. 2000; Xu \& Qi, 2001; Raich et al., 2002; Hibbard et al., 2005). However, on short time scales, variation in soil $\mathrm{CO}_{2}$ flux is mainly driven by soil temperature and moisture (e.g. Raich \& Schlesinger, 1992; Peng \& Thomas, 2006). The $\mathrm{CO}_{2}$ emission from soil increases exponentially with increasing temperature when any other factors and resources are not limiting (Lloyd \& Taylor, 1994) that often is modelled through $\mathrm{Q}_{10}$ coefficient. However, many studies report large variability of $\mathrm{Q}_{10}$ for the same sites during the growth season, e.g. from 1.98 to 5.00 for sod-poszolic soils and from 1.72 to 6.20 for grey forest soils (Kurganova, 2010), that may generate uncontrolled biases in the results. The relationship between intensity of soil $\mathrm{CO}_{2}$ flux and soil moisture can be described by an upward convex curve (Peng et al, 2008).

Russian forest is a significant element of the global carbon budget (Pan et al., 2011), and hence they can play an important role in climate change mitigation. They comprise about $23 \%$ of the entire world's forest area. Forest land and forested area (closed forests) cover 51.6\% and $45.3 \%$ of the total land area of the country respectively (Onuchin et al., 2009). These forest areas contain $21 \%$ of the world's growing stock, and $13 \%$ of the live forest biomass of the globe (FAO, 2009). They keep about $43 \mathrm{Pg} \mathrm{C}$ in terrestrial vegetation including $35 \mathrm{Pg} \mathrm{C}$ in live biomass (Shvidenko et al., 2007, 2009).

Current science on climate change has been coming to understanding of need of a Terrestrial Ecosystems Full and Verified Carbon Account (FCA). Uncertainty of the FCA is crucially driven by uncertainty of $\mathrm{R}_{\mathrm{S}}$ and particularly its heterotrophic part (Shvidenko et al., 2010). The major objective of this study is assessing the soil contribution to the current carbon budget of Russian forests aiming at uncertainty's level that would not exceed some certain levels acceptable for policy makers. The latter still remains a topic of discussions. Some studies indicate a presumptive level of \pm 20 -25\% (CI 0.9) for Net Ecosystem Carbon Budget at the continental scale (Nilsson et al., 2007). It means that uncertainty of $\mathrm{R}_{\mathrm{h}}$ should not exceed this threshold. While a wide range of climatic conditions, diversity of landscapes and forest ecosystems and other drivers over the vast territory of Russian forests results in a large temporal and spatial variety of soil respiration, this study attempted to understand whether the FCA of forest ecosystems is achievable under proper organization of the information background and consistent application of systems (holistic) analysis. The paper also includes some results on forest soil carbon stock that have been earlier published in an aggregated form (Schepaschenko et al., 2013) taking into account relevance of consideration of links between the amount of carbon and heterotrophic respiration. 


\section{Materials and methods}

\subsection{Assessment of soil carbon pool}

The soil organic carbon (SOC) pool was calculated separately for the topsoil organic O horizon (FAO, 2006) and for 1m of soil below. The soil map of the Russian Federation at a scale of 1:2.5 million and a reference soil profiles' database (modified by authors from Stolbovoi \& McCallum, 2002) were used to calculate the SOC pool for typical soil profiles and their distribution over the country. A database of soil carbon measurements (1068 records) was collected from published papers. It was used for accounting of zonal/regional specificity of SOC storage, vegetation type and land-use impact via a special system of correction coefficients.

The method of assessment of the SOC pool is described in details in Schepaschenko et al., (2013).

\subsection{Soil respiration database}

We collected the majority of studies on Rs measurements in situ that were reported in peer-reviewed scientific literature and organized the reported results into a database. A substantial part of the data was picked up from the global database by Bond-Lamberty and Thomson (2010) that accounted for 3379 records from 818 studies. We have taken from this database only the records for the extra-tropical northern hemisphere where annual $\mathrm{R}_{\mathrm{S}}$ flux or mean seasonal rate of $\mathrm{R}_{\mathrm{S}}$ were reported or root contribution to the total carbon flux from soil was presented. Data from another 291 sources were collected by us on the same basis especially focusing on Russia. We aim to contribute this data to global database by BondLamberty and Thomson.

In total, about 810 studies were used and 2254 records on $\mathrm{R}_{\mathrm{S}}$ fluxes in arctic, boreal and temperate biomes were collected, spanning the measurement years 1961-2008. The regions representфешщт is following: Northern America - 1055 records, Europe - 833 and Asia - 366 (Fig.1). Data from temperate ecosystems dominate the database $(n=1287)$, and the boreal zone is represented by 735 records. Most of the data came from forests $(n=1417)$, while grasslands $(n=243)$ and arable $(n=131)$ land are less represented. 


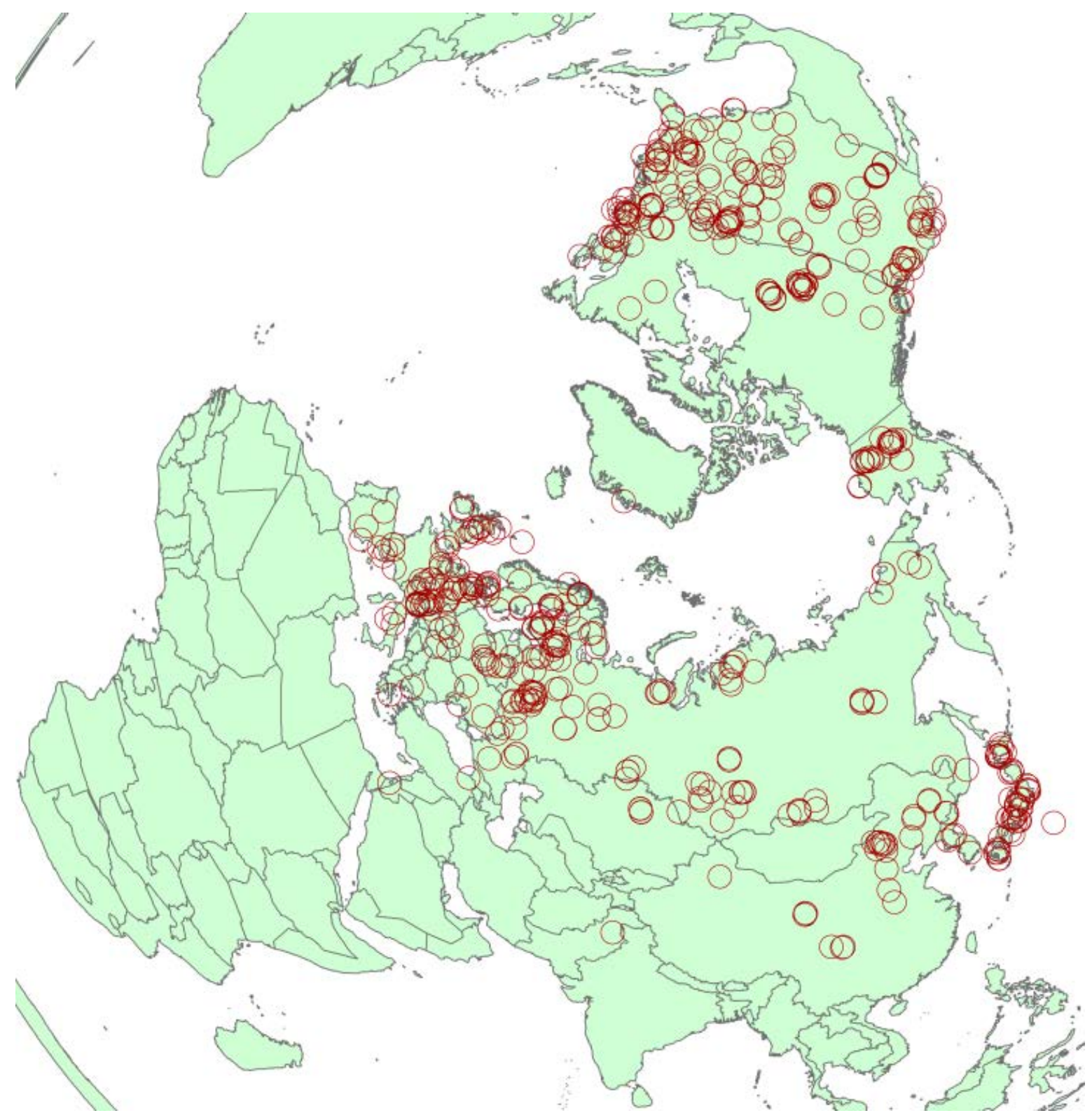

Fig.1. Locations of collected database observations of the northern hemisphere.

The magnitude of annual Rs flux varied from 1 to $6596 \mathrm{~g} \mathrm{C} \mathrm{m}^{-2} \mathrm{yr}^{-1}$ for all ecosystems and the majority of records varied between 100 to $1000 \mathrm{~g} \mathrm{C} \mathrm{m}^{-2} \mathrm{yr}^{-1}$.

Besides $\mathrm{R}_{\mathrm{s}}$ measured value, the database contains information on climatic zone, vegetation class, soil group and 15 climatic characteristics (Table 1) for the year of measurements.

Climate data (temperature and precipitation) for the period 1974-2008 were obtained from FOODSEC (http://mars.jrc.ec.europa.eu/mars/About-us/FOODSEC/Data-Distribution). FOODSEC receives daily, ten-days and monthly outputs of the ECMWF (European Centre for Medium-Range Weather Forecast) global circulation model and provides the data aggregated for 10-day periods. The original global data are at 0.25 degree resolution. The data are provided by the ERA40 historical reanalysis time series project at 0.5 degree resolution.

Table 2 contains a list of climatic parameters we calculated for each year between 1974 and 2008 based on FOODSEC reanalysis. 
Table 1.

Listing of climate attributes calculated for years 1974-2008

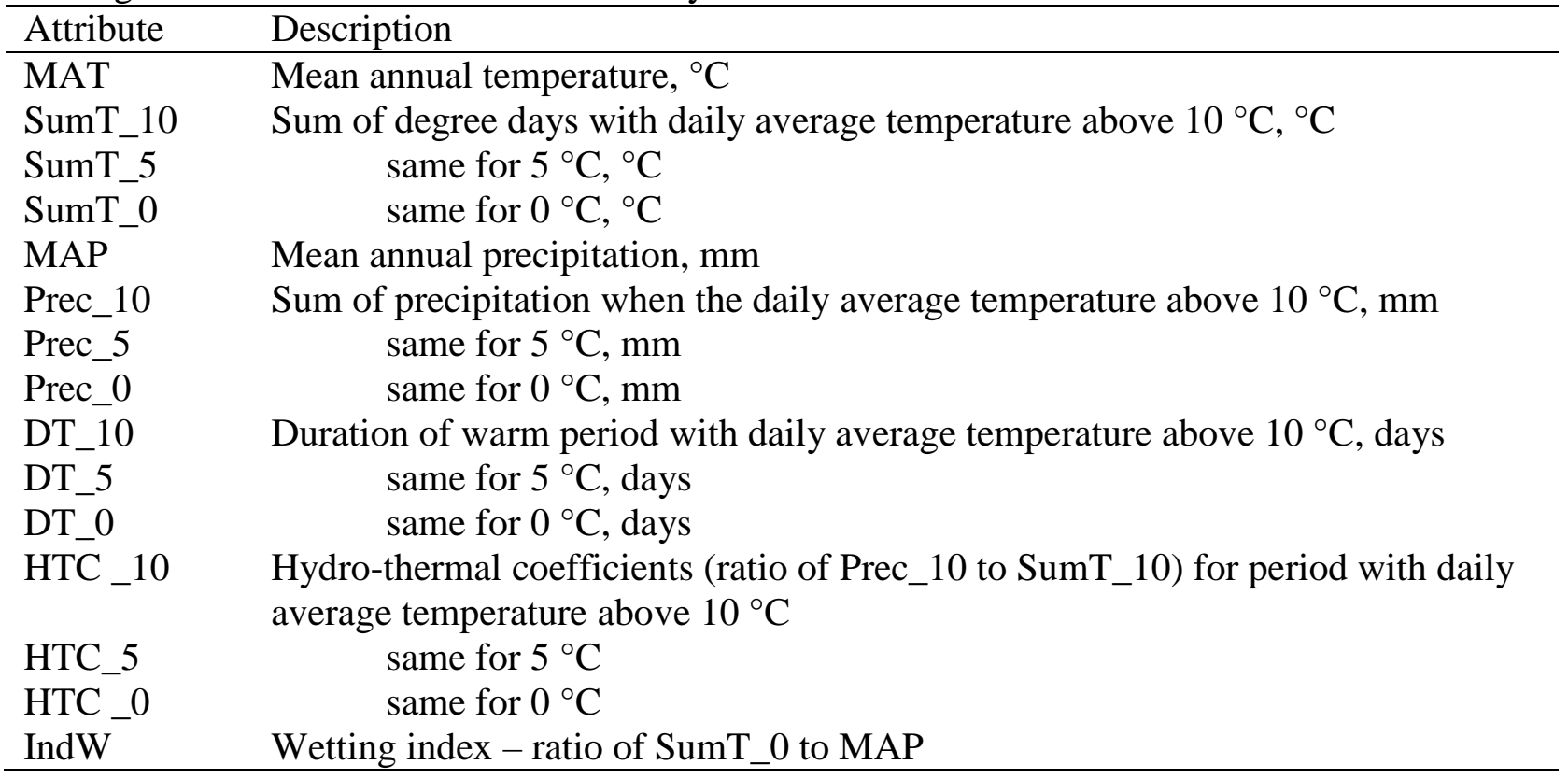

The climate grids were then overlaid with the plot locations and the climate information was extracted for each plot and placed in the database for the year of measurement. For the measurements made before 1974 or without clear date (all together around $10 \%$ ) we had to apply multiyear average climatic parameters.

\subsection{Calculation of annual soil respiration flux from growing season measurements}

The primary Rs unit used was g C m $\mathrm{yr}^{-1}$ (for annual fluxes). Some studies reported only the mean rate of $\mathrm{Rs}_{\mathrm{s}}$ efflux $\left(\mu \mathrm{mol} \mathrm{C} / \mathrm{m}^{2} \times \mathrm{s}^{-1}\right.$ ) measured during the growing season (Rs_growing). For these cases growing season respiration flux $\left(\mathrm{g} \mathrm{C} \mathrm{m}^{-2}\right)$ was calculated by the following equation:

$$
\text { Rs_DT_5=12×Rs_growing } \times 10^{-6} \times 60 \times 60 \times 24 \times \text { DT_5, }
$$

where Rs_DT_5 - C-CO $\mathrm{CO}_{2}$ efflux during period with mean daily temperature above $5^{\circ} \mathrm{C}, \mathrm{g} \mathrm{C}$ $\mathrm{m}^{-2}$; DT_5 - duration of the warm period with mean daily temperature above $5^{\circ} \mathrm{C}$; $(60 \times 60 \times$ 24) - recalculation of efflux $\mu \mathrm{mol} \mathrm{C} / \mathrm{m}^{2} \times \mathrm{s}^{-1}$ to the $\mu \mathrm{mol} / \mathrm{m}^{2} \times \mathrm{d}^{-1} ; 12$ - a molar mass of carbon to convert $\mu \mathrm{mol}$ of $\mathrm{C}$ into the gram of $\mathrm{C}$.

To calculate the annual flux of $\mathrm{R}_{\mathrm{S}}$ a regression model was developed based on the data from studies where both annual and seasonal respiration fluxes were reported $(n=130)$ :

$$
\mathrm{R}_{\mathrm{S}}=101.5309+0.5967 \times \mathrm{DT} \_5+0.7087 \times \mathrm{Rs} \_\mathrm{DT} \_5, \quad \mathrm{R}^{2}=0.81, \mathrm{p}<0.01
$$

where $\mathrm{R}_{\mathrm{S}}$ is annual $\mathrm{R}_{\mathrm{S}}$ flux, g $\mathrm{C} \mathrm{m} \mathrm{m}^{-2} \mathrm{yr}^{-1}$; DT_5 - duration of the warm period with mean daily temperature above $5{ }^{\circ} \mathrm{C}$; Rs_DT_5 - C-CO $\mathrm{CO}_{2}$ efflux during period with mean daily temperature above $5^{\circ} \mathrm{C}$. 


\subsection{Modeling of soil respiration flux}

The role of climatic factors in Rs efflux was analyzed using method of multiple linear regression analyses. We tested full set of climatic parameters listed in Table 1 and left significant once in the final equations presented in the section 3.2.

$\mathrm{R}_{\mathrm{S}}$ is an integrative flux that reflects internal soil properties as well as biotic and abiotic influence on the soil. Vegetation cover influences this flux regulating the microclimatic conditions, amount of organic matter and root biomass, which is responsible for the autotrophic respiration component. Raich \& Tufekciogul (2000) have found that soil respiration rate under coniferous forests was about $10 \%$ lower in comparison with adjacent deciduous forests growing on the same soil type. We conducted a regression analysis of $\mathrm{R}_{\mathrm{S}}$ depending on climatic parameters separately for deciduous, coniferous and mixed forest.

Soil type reflects certain water regimes, vegetation type and implies amount of organic matter to decompose. Moreover, soil transforms the climate's influence. Average Rs rate was calculated by individual soil groups according to collected Rs records (Table 2).

Table 2.

Average soil respiration flux for different soil groups

\begin{tabular}{|c|c|c|c|}
\hline & Soil group ${ }^{\mathrm{a}}$ and their description & $\mathrm{N}$ & $\begin{array}{l}\text { Average } \mathrm{R}_{\mathrm{s}}, \\
\mathrm{g} \mathrm{C}^{-2} \mathrm{yr}^{-1} \pm 1 \mathrm{sd}^{\mathrm{b}}\end{array}$ \\
\hline 1 & Cryosols - soils of cold permafrost regions & 23 & $197 \pm 118$ \\
\hline 2 & Gleysols or Gleyzems - overwetted soils with gleyic horizon & 138 & $540 \pm 292$ \\
\hline 3 & Podzol - soils with light podzolic horizon & 307 & $622 \pm 266$ \\
\hline 4 & $\begin{array}{l}\text { Cambic Podzol or Podbur - Al-Fe-Humic cold soils without } \\
\text { clear podzolic horizon }\end{array}$ & 46 & $413 \pm 254$ \\
\hline 5 & Luvisols and Greyzems - texture-differentiated soils & 424 & $785 \pm 437$ \\
\hline 6 & $\begin{array}{l}\text { Gleysols - overwetted mineral soils with thick }(10-30 \mathrm{~cm}) \\
\text { organic horizon }\end{array}$ & 52 & $577 \pm 352$ \\
\hline 7 & Histosols - overwetted organic soils & 227 & $472 \pm 274$ \\
\hline 8 & $\begin{array}{l}\text { Cambisols or Metamorphic soils - soil is made from the } \\
\text { weathering of schist, slate, or gneiss without substantial } \\
\text { redistribution of Fe in the soil profile }\end{array}$ & 442 & $765 \pm 399$ \\
\hline 9 & $\begin{array}{l}\text { Phaeozems, Histosols and Leptosols - sod-organic } \\
\text { accumulative soils }\end{array}$ & 18 & $582 \pm 429$ \\
\hline 10 & Chernozems and Kastanozems - humic-accumulative soils & 227 & $723 \pm 383$ \\
\hline 11 & Andosols - soils on volcanic parent materials & 98 & $1114 \pm 567$ \\
\hline 12 & $\begin{array}{l}\text { Fluvisols - soil is formed under deposition of alluvial } \\
\text { material }\end{array}$ & 41 & $894 \pm 650$ \\
\hline 13 & $\begin{array}{l}\text { Calcisols and Solonetz - low-humic, accumulative calcareous } \\
\text { soils. It has a fairly high pH and is alkaline }\end{array}$ & 60 & $392 \pm 233$ \\
\hline 14 & $\begin{array}{l}\text { Leptosols - shallow weakly developed soils with a short } \\
\text { profile }\end{array}$ & 139 & $690 \pm 447$ \\
\hline 15 & Umbrisols and Regosols - sod mountain soils & 11 & $367 \pm 301$ \\
\hline
\end{tabular}

${ }^{a}$ Soil is named in accordance with WRB (IUSS, 2006). ${ }^{\mathrm{b}}$ Standard deviation of by-pixel values.

We calculated regression equations for every soil group listed in table 2 dependently climatic parameters. The results are presented in section 3.2 (Table 4).

Individual soil groups cover vast areas in Russian forests. In spite of similar genesis and general soil properties within the groups, there are wide ranges of carbon content, horizons thickness and other soil properties. This leads to variation of Rs (Table 2). Moreover, Rs varies with vegetation type and disturbances. In order to take into account particularities of 
regional $R_{S}$, as well as influence of vegetation and disturbances, we introduced correction coefficients. They are based on comparison of measured and calculated Rs (via climatic dependent models, presented in the Table 4).

We calculated Rs for every record in the database of in situ measurements and compared results within soil group, region, bioclimatic zone and vegetation type. The correction coefficients are represented by ratio [3] of average $\mathrm{R}_{\mathrm{S}}$ from the database to $\mathrm{R}_{\mathrm{S}}$ calculated by the models of Table 4

[3] $K=\frac{R_{S}^{\text {DBaverage }}}{R_{S}^{\bmod }}$.

Similar correction coefficients were calculated for every soil group (Table 2), region (European and Asian part of Russia), zone (tundra, northern \& sparse taiga, middle taiga, southern taiga, temperate forests, steppe, semi-desert) and vegetation type (coniferous, deciduous and mixed forest). These coefficients allow us to take into account factors, which are not directly associated with temperature and precipitation.

\subsection{Assessment of autotrophic soil respiration}

Total soil $\mathrm{CO}_{2}$ efflux is composed of respiration of roots, associated rhizosphere and soil microorganisms. The partitioning of soil $\mathrm{CO}_{2}$ efflux helps to improve our understanding of the environmental changes that drive carbon cycling (Bond-Lamberty et al., 2004) and more accurately estimate turnover rates of soil organic matter and carbon budgets of ecosystems (Wang et al., 2006).

As far as root respiration is attributed to the plant physiological functions it seems reasonable that this flux depends on vegetation type and plant growth activity.Plant roots can contribute from 10 to $90 \%$ of total carbon flux from soil dependent upon vegetation type and growth activity (e.g. Wang et al., 2006). Yevdokimov et al. (2010) reported that root contribution in grassland ecosystems varied from 24 to $60 \%$, in forests - from 7 to $56 \%$. Hanson et al., (2000) summarized the results of 51 previous studies where the root contribution to total soil $\mathrm{CO}_{2}$ efflux was determined. In this study the root contribution averaged $45.8 \%$ and $60.4 \%$ for forest and non-forest vegetation, respectively.

Evidently that share of root and microbe contributions to the total $\mathrm{CO}_{2}$ efflux from soil depends upon the climate. In order to estimate the $\mathrm{R}_{\mathrm{A}}$ component of $\mathrm{R}_{\mathrm{S}}$ flux and its dependence on climatic conditions, we built regression models (separately for coniferous and deciduous dominant species) to calculate the impact of climate on the share of autotrophic respiration $\left(R_{A} \%\right)$ in $R_{s}$. We use the same database described in section 2.2 to build the models. The results are given in the section 3.3.

\subsection{Calculation of heterotrophic soil respiration}

Heterotrophic soil respiration $\left(\mathrm{R}_{\mathrm{h}}\right)$ was calculated as a difference between total soil respiration $\left(\mathrm{R}_{\mathrm{S}}\right)$ and autotrophic respiration $\left(\mathrm{R}_{\mathrm{A}}\right)$,

$$
R_{h}=R_{s}\left(1-\frac{R_{A \%}}{100}\right)
$$

\subsection{Impacts of disturbances}

Wild fire and harvesting are main disturbing factors in Russian forests. On average $5 \mathrm{mln}$ ha of forested areas burn every year in Russia (Shvidenko et al., 2011), while about 0.85 mln ha are harvested annually. All together it amounts to about $0.7 \%$ of total forested area in the country per year. 
There are a large number of publications that report data on consumption of litter and upper layers of soils by different types of fire (e.g., see a review in Shvidenko, Nilsson, 2000). Based of analysis of available data, Schepaschenko et al. (2013) concluded that $40 \%$ of litter is on average burn under fire in Russian forests. Such a coefficient was applied to the burnt areas during the last decade for the assessment of soil carbon stock. We did not do any corrections for logged areas taking into account inconsistency of experimental data: numerous publications reported that harvest can as reduce soil carbon by $6-50 \%$ as increase soil carbon stock by $7-100 \%$ if logging slash was not removed from the cutting sites (Johnson \& Curtis, 2001; Sin'kevich et al., 2009; Masyagina et al., 2010; Nave et al., 2010; Vedrova et al., 2010; Bezkorovaynaya et al., 2010; Mukhortova, 2012).

Both these disturbances produce a substantial amount of woody detritus. Coarse woody debris may cover as much as $25-60 \%$ of the soil surface in forests disturbed by fire (Tinker \& Knight, 2000; Hely et al., 2000; Spears et al., 2003; Nave et al., 2011). In post-logging forests stock of coarse woody debris (CWD) and woody slash can substantially exceed live biomass pool and reach up to 63-80 \% of total carbon stock in these ecosystems (Mukhortova, 2012). The total amount of carbon in CWD in Russian forests is estimated at 7.0 Pg C or 8.6 Mg C $h^{-1}$ (Shvidenko, Schepaschenko, 2014). The flux due to decomposition of CWD was not included in $\mathrm{R}_{\mathrm{H}}$ but was accounted in the total ecosystem heterotrophic respiration (Section 5). Soil respiration can decrease by $4-50 \%$ after fire and by 5-40\% after harvest (Tan et al., 2012; Meigl et al., 2009; Amiro et al., 1999; Maranon-Jimenez et al., 2011; Edmonds et al., 2000; Saynes et al., 2012; Streigl et al., 1998; Singh et al., 2008). On the contrary, some authors report respiration's increase up to 100\% after disturbances (Concilio et al., 2005; Saynes et al., 2012; Olajujigbe et al., 2012; Popova \& Perevozchikova, 1996; Maranon-Jimenez et al., 2011). Time of recovery of soil respiration is ranged from 3 to 20 years after harvest (Concilio et al., 2006; Saynes et al., 2012; Sin'kevich et al., 2009; Popova \& Perevozchikova, 1996; Nave et al., 2010) and 5-40 years after fire (Hicke et al., 2003; Nave et al., 2011; Wirth et al., 2002; Norris et al., 2009; Burke et al., 1997; Amiro et al., 1999). Due to large discrepancies in reported experimental results, we did not correct $\mathrm{R}_{\mathrm{H}}$ on burnt and harvested areas.

\subsection{Assessment of uncertainties}

Different sources of uncertainties impact the results of this study. They include lack of strict spatial and temporal planning of sampling inventories, not completely compatible definitions of parameters and protocols of measurements, completeness of accounting for major drivers and processes, errors of models used, limitations in understanding of the processes that control pool sizes and fluxes, lack of informative and solid gradients for upscaling etc. (Birdsey \& Heath, 1995; Nilsson et al., 2007; Shvidenko et al., 2010).

Overall, assessment of heterotrophic respiration for large territories is a typical fuzzy task (Shvidenko et al., 2010), or - in other terminology - a full complexity problem (Schellnhuber, 2003). Any method used individually for studying such systems cannot estimate the structural uncertainty (Shvidenko et al., 2010). In this study we tried to comprehensively follow the requirements of the applied system analysis taken into account the fuzzy specificity of the studied systems. The assessment of uncertainties was provided in the following steps: (1) estimation of precision of intermediate and final results using error propagation theory; (2) "transformation" of precision into uncertainty based on sensitivity of analysis (using the Monte-Carlo method) and expert estimate of unaccounted impacts and processes; and (3) multiple-constraint comparison of results. Details of the approach are considered in (Nilsson et al., 2007; Shvidenko et al., 2010). We have to note that the reported uncertainties (1) to some extent include formalized expert estimates, thus "uncertainties of 
uncertainties" do not have strict formal proofs, and (2) the numerical results were received under assumption that the accounting schemes have no unrecognized biases.

One of the key controls on carbon stock and fluxes is the land cover, which is itself highly dynamic. We used a detailed forest map of high quality with resolution of $1 \mathrm{~km}$ (the state for 2010) which is based on the integration of multi-sensor remote sensing and ground data (Schepaschenko et al., 2011). The sensitivity analysis showed that the land cover uncertainties are substantially smaller than those caused by other factors. The soil map was less certain. The main uncertainties here arose from potential biases due to the rough spatial scale, availability of large (particularly, remote) areas without measurements, possible misclassification etc. Numerical assessment of uncertainties of input data (areas and parameters used) was based on reported estimates and professional judgments.

Uncertainties of model simulations generally depend upon system consistency of input data, model parameters, and model structure (e.g., Enting et al., 2012). In our calculation of multi-dimensional regressions, some uncertainties followed from using the database for the entire northern hemisphere which might include data of field measurements that are based on not completely compatible definitions and protocols, sometimes were incomplete and required recalculations. We examined a wide set of analytical expressions and checked their quality by statistical rules (including analysis of residuals). However, the structural consistency of the models could not be strictly estimated due to lack of independent estimates which would properly report the corresponding uncertainties. While our modeling approach on assessing and separation of total soil respiration in autotrophic and heterotrophic parts likely does not have substantial unrecognized biases, the statistical accuracy of some models is moderate. Below we present only the "best" (by statistical significance and adequacy) equations of many equations which have been examined.

\section{Results}

\subsection{Forest soil carbon pool}

Our estimates of carbon content of soils of Russian forests (SOC) is $144.5 \mathrm{Pg} \mathrm{C}$, and $94.2 \%$ of this amount is allocated in the $1 \mathrm{~m}$ soil layer and the rest $(5.8 \%)$ is contributed by the on-ground organic layer (Table 3) - the SOC pool with a fast turnover rate. About $81 \%$ of the total SOC pool of Russian forests is located in the Asian part of Russia that comprises $79.5 \%$ of the total forested area of the country. A majority of the SOC stock is related to boreal forests (83\% and 93\% in European and Asian Russia, respectively). 
Table 3.

Carbon pools in soil of Russian forests

\begin{tabular}{|c|c|c|c|c|}
\hline \multirow[b]{2}{*}{ Region/Zone } & \multicolumn{2}{|c|}{ Horizon O } & \multicolumn{2}{|c|}{ Top 1m layer of soil } \\
\hline & Tg C & kg C m$~ m^{-2}$ & $\operatorname{Tg} \mathrm{C}$ & $\mathrm{kg} \mathrm{C} \mathrm{m}^{-2}$ \\
\hline \multicolumn{5}{|l|}{ European part } \\
\hline Tundra & 35 & 0.86 & 1142 & 27.99 \\
\hline Forest tundra, northern \& sparse taiga & 331 & 0.97 & 6376 & 18.70 \\
\hline Middle Taiga & 589 & 1.04 & 7205 & 12.71 \\
\hline Southern Taiga & 514 & 0.92 & 7632 & 13.67 \\
\hline Temperate forests & 106 & 0.91 & 1904 & 16.21 \\
\hline Steppe & 27 & 0.50 & 1329 & 24.92 \\
\hline Desert \& semi-desert & 1 & 0.39 & 49 & 17.56 \\
\hline Subtotal & 1604 & 0.95 & 25637 & 15.26 \\
\hline \multicolumn{5}{|l|}{ Asian part } \\
\hline Tundra & 192 & 1.14 & 2870 & 17.02 \\
\hline Forest tundra, northern \& sparse taiga & 1197 & 1.14 & 22000 & 20.87 \\
\hline Middle Taiga & 4205 & 1.02 & 61192 & 14.85 \\
\hline Southern Taiga & 832 & 0.91 & 19524 & 21.40 \\
\hline Temperate forests & 203 & 1.26 & 2487 & 15.47 \\
\hline Steppe & 88 & 0.82 & 2341 & 21.88 \\
\hline Desert \& semi-desert & 3 & 0.48 & 110 & 16.68 \\
\hline Subtotal & 6719 & 1.03 & 110523 & 16.93 \\
\hline Total Russia & 8323 & 1.01 & 136160 & 16.59 \\
\hline
\end{tabular}

The average SOC density is high in tundra and steppe forests (up to $22-28 \mathrm{~kg} \mathrm{C} \mathrm{m}^{-2}$ ). The main reason for such a large stock is low temperature in the north and dry conditions in the steppe zone that both inhibit the microbial activity in soil.

\subsection{Regression models of total soil respiration}

The $\mathrm{R}_{\mathrm{S}}$ database confirms that different forest types have distinct $\mathrm{R}_{\mathrm{S}}$ rates. Soil under coniferous forests has lower carbon dioxide emission in comparison with soils of deciduous and mixed forest, which have $30 \%$ and $70 \%$ higher $\mathrm{R}_{\mathrm{S}}$ rate respectively. Likely, the main reason of such a difference is lower litterfall and slower growth rate of coniferous species that can lead both to the lower root respiration flux and to the lower input of forest litter plant material.

Multiple linear regression analysis suggests that $R_{S}(n=2254)$ mostly depends on accumulated temperatures during frost free period and wetting conditions of the site (here and below only statistically significant factors are included in the equations):

[5] $\quad \ln \left(\mathrm{R}_{\mathrm{S}}\right)=1.3428+0.6591 \times \ln ($ SumT_0 $)-0.2037 \times \ln (\operatorname{IndW}), \quad \mathrm{R}^{2}=0.43, \mathrm{p}<0.01$ where $\mathrm{R}_{\mathrm{S}}$ denotes annual soil respiration flux, g $\mathrm{C} \mathrm{m}^{-2} \mathrm{yr}^{-1}$; SumT_0 - accumulated daily average temperatures during the frost free period, ${ }^{\circ} \mathrm{C}$; IndW -wetting index (ratio of SumT_0 to annual precipitation).

Variation of $\mathrm{Rs}_{\mathrm{s}}$ under the coniferous forests $(\mathrm{n}=646)$ can be described by 4 climatic parameters: duration of frost free period (D_0) and accumulated temperature for the same span (SumT_0), annual amount of precipitation (MAP) and wetting (IndW):

[6] $\quad \ln \left(\mathrm{R}_{\mathrm{S}}\right)=0.6499-11.2395 \times \ln \left(\operatorname{SumT} \_0\right)+11.4742 \times \ln (\mathrm{MAP})+0.7320 \times \ln \left(\mathrm{D} \_0\right)+$

$$
+11.2473 \times \ln (\operatorname{IndW}), \quad \mathrm{R}^{2}=0.41, \mathrm{p}<0.01
$$


Deciduous forest $R_{S}(n=647)$ has a weaker link with climatic variables, and the most significant periods for carbon release from these soils are warmer seasons with mean daily temperatures above $5^{\circ} \mathrm{C}$ and $10^{\circ} \mathrm{C}$ :

[7] $\ln \left(\mathrm{R}_{\mathrm{S}}\right)=1.5515-0.9254 \times \ln \left(\mathrm{SumT} \_10\right)+2.1301 \times \ln (\mathrm{MAP})-0.9113 \times \ln \left(\mathrm{D} \_5\right)+$

$$
+2.0674 \times \ln (\operatorname{Ind} W), \quad \mathrm{R}^{2}=0.35, \mathrm{p}<0.05 \text {, }
$$

where SumT_10 - accumulated daily average temperatures during the period with mean daily air temperatures above $10^{\circ} \mathrm{C}$, ${ }^{\circ} \mathrm{C}$; MAP - annual precipitation, mm; D_5 - duration of the period with mean daily air temperatures above $5^{\circ} \mathrm{C}$, days; IndW - wetting index.

An improved relationship between $\mathrm{R}_{\mathrm{S}}$ and climatic drivers was observed for both deciduous and mixed forests considered together $(\mathrm{n}=771)$ :

[8] $\quad \ln \left(\mathrm{R}_{\mathrm{S}}\right)=1.2799-0.8816 \times \ln \left(\operatorname{SumT} \_10\right)+2.0686 \times \ln (\mathrm{MAP})-0.8296 \times \ln \left(\mathrm{D} \_5\right)+1.9863 \times$

$$
\times \ln (\operatorname{Ind} \bar{W}), \quad \mathrm{R}^{2}=0.41, \mathrm{p}<0.05
$$

However $R_{S}$ in mixed forests alone $(n=124)$ strongly depends on the same climatic variables as coniferous forests:

[9] $\ln \left(\mathrm{R}_{\mathrm{S}}\right)=2.7745+11.6585 \times \ln ($ SumT_0 $)-10.6361 \times \ln (\mathrm{MAP})-0.7890 \times \ln \left(\mathrm{D} \_0\right)-10.8380 \times$

$$
\ln (\operatorname{IndW}), \quad \mathrm{R}^{2}=0.63, \mathrm{p}<0.01
$$

Average $\mathrm{R}_{\mathrm{S}}$ rate calculated by individual soil groups according to collected $\mathrm{R}_{\mathrm{S}}$ records (Table 2) showed that the lowest $\mathrm{R}_{\mathrm{s}}$ is attributed to cold arctic tundra soils. Sod mountain and peat soils have a low $\mathrm{R}_{\mathrm{S}}$ efflux as well. In both cases it follows from unfavorable conditions for the root growth and microbial activity. In sod-mountain soils the limiting factor is temperature and for peat soil - overwetting conditions. warm volcanic soils as well as fluvisols have highest Rs rate in comparison with other soil groups.

Rich with organic matter chernozems, cambisols and luvisols have a similar $\mathrm{R}_{\mathrm{S}}$ rate of about 765-785 $\mathrm{g} \mathrm{C} \mathrm{m}^{-2} \mathrm{yr}^{-1}$. Poorer calcisols and podzols have respiration rate from 392 to 622 g C m ${ }^{-2} \mathrm{yr}^{-1}$.

The best dependence of $\mathrm{R}_{\mathrm{S}}$ on climatic variables was obtained for soil groups independently upon vegetation classes (Table 4). 
Table 4.

Models of soil respiration flux for different soil groups

\begin{tabular}{|c|c|c|c|c|}
\hline $\begin{array}{l}\text { Soil } \\
\text { group }\end{array}$ & $\mathrm{N}$ & $\mathrm{R}^{2}$ & $\begin{array}{l}\text { p- } \\
\text { level }\end{array}$ & Model \\
\hline 1 & 23 & 0.71 & $<0.01$ & $\begin{array}{l}\ln \left(R_{S}\right)=1.7965+0.8063 \times \ln \left(\mathrm{D} \_0\right)-0.8013 \times \ln \left(\mathrm{D} \_5\right)- \\
-0.4479 \times \ln \left(\mathrm{P} \_0\right)+1.1433 \times \ln \left(\mathrm{P} \_5\right)\end{array}$ \\
\hline 2 & 138 & 0.64 & $<0.01$ & $\begin{array}{l}\ln \left(\mathrm{R}_{\mathrm{S}}\right)=-5.9300+0.7123 \times \mathrm{HTC} \_0-0.5591 \times \operatorname{IndW}+ \\
+1.3809 \times \ln (\mathrm{MAP})-0.2899 \times \ln \left(\mathrm{P} \_5\right)+4.0638 \times \ln (\mathrm{IndW})\end{array}$ \\
\hline 3 & 307 & 0.40 & $<0.01$ & $\ln \left(\mathrm{R}_{\mathrm{S}}\right)=-3.136+1.508 \times \ln \left(\mathrm{D} \_0\right)+0.223 \times \ln \left(\mathrm{P} \_10\right)-0.305 \times \ln \left(\mathrm{HTC} \_10\right)$ \\
\hline 4 & 46 & 0.29 & $<0.01$ & $\ln \left(\mathrm{R}_{\mathrm{S}}\right)=5.5414+0.0049 \times(\mathrm{P} \quad 10)-0.0019 \times(\mathrm{P} 0)$ \\
\hline 5 & 424 & 0.45 & $<0.01$ & $\ln \left(\mathrm{R}_{\mathrm{S}}\right)=5.3687+0.000810 \times($ SumT_0 $)-0.000614 \times($ SumT_10 $)$ \\
\hline 6 & 52 & 0.32 & $<0.01$ & $\ln (\mathrm{Rs})=-2.9816+0.5626 \times \ln \left(\mathrm{P} \_10\right)$ \\
\hline 7 & 227 & 0.25 & $<0.01$ & Rs $=385.252-4.601 \times\left(\mathrm{D} \_10\right)+0.245 \times($ SumT_0 $)$ \\
\hline 8 & 442 & 0.25 & $<0.05$ & $\begin{array}{l}\ln \left(\mathrm{R}_{\mathrm{S}}\right)=10.9183-2.1947 \times \ln \left(\operatorname{SumT} \_0\right)-0.0166 \times\left(\mathrm{D} \_10\right)+ \\
+0.0012 \times(\text { SumT_5 })+2.3921 \times \ln \left(\mathrm{HTC} \_0\right)-0.00096 \times\left(\mathrm{P} \_0\right)- \\
-0.3078 \times \ln \left(\mathrm{HTC} \_10\right)+1.9535 \times \ln \left(\mathrm{D} \_10\right)+0.8293 \times \ln (\mathrm{IndW})\end{array}$ \\
\hline 9 & 18 & 0.81 & $<0.01$ & $\begin{array}{l}\ln \left(R_{S}\right)=8.7319+0.1951 \times \text { MAT-0.0028 } \times\left(\mathrm{D} \_10\right)-0.0027 \times\left(\mathrm{P} \_0\right)- \\
0.3337 \times(\mathrm{IndW})\end{array}$ \\
\hline 10 & 227 & 0.33 & $<0.01$ & $\begin{array}{l}\ln \left(\mathrm{R}_{\mathrm{S}}\right)=0.6586-0.0013 \times\left(\mathrm{D} \_5\right)-0.0021 \times\left(\mathrm{P} \_0\right)+0.0019 \times\left(\mathrm{P} \_5\right) \\
+0.0035 \times \ln \left(\mathrm{D} \_0\right)+0.9836 \times \ln \left(\mathrm{P} \_5\right)-0.0014 \times \ln \left(\mathrm{P} \_10\right)\end{array}$ \\
\hline 11 & 98 & 0.48 & $<0.01$ & Rs $=-652.208+8.068 \times\left(\mathrm{D} \_5\right)-0.549 \times\left(\mathrm{P} \_5\right)$ \\
\hline 12 & 41 & 0.91 & $<0.01$ & $\begin{array}{l}\ln \left(\mathrm{R}_{\mathrm{S}}\right)=15.655+0.618 \times \mathrm{MAT}+0.0021 \times \mathrm{MAP}-0.0284 \times\left(\mathrm{D} \_0\right) \\
-0.0016 \times(\text { SumT_5 })+1.809 \times(\text { HTC_5 })-3.287 \times(\text { HTC_10 })\end{array}$ \\
\hline 13 & 60 & 0.83 & $<0.05$ & $R s=-322.17+2.170 \times\left(\mathrm{P} \_5\right)+6.155 \times\left(\mathrm{D} \_0\right)-4.968 \times\left(\mathrm{D} \_5\right)-1.501 \times\left(\mathrm{P} \_0\right)$ \\
\hline 14 & 139 & 0.51 & $<0.05$ & $\begin{array}{l}\ln \left(\mathrm{R}_{\mathrm{S}}\right)=-144.626-0.002 \times \mathrm{MAP}-0.113 \times\left(\mathrm{D} \_0\right)+0.002 \times\left(\mathrm{P} \_5\right) \\
+29.894 \times \ln \left(\mathrm{D} \_0\right)+7.212 \times \ln (\text { SumT_5 })-5.458 \times \ln (\text { SumT_10 })\end{array}$ \\
\hline 15 & 11 & 0.95 & $<0.01$ & $\ln \left(\mathrm{R}_{\mathrm{S}}\right)=-38.169-0.0528 \times\left(\mathrm{D} \_0\right)+7.311 \times \ln ($ SumT_5 $)$ \\
\hline
\end{tabular}

${ }^{a}$ Soil groups are the same as in the table 2.

\subsection{Regression models of autotrophic respiration}

We have collected above 440 records on root contribution to the total $\mathrm{R}_{\mathrm{S}}$ flux from relevant studies. The distribution of collected records on root contribution is near-normal. The average share of autotrophic part to the total $R_{S}$ flux under the forest vegetation $(n=292)$ is $44 \%$ varying from 2 to $96 \%$ and in most cases is between 20 to $60 \%$.

The distribution of collected records of corresponding mean annual temperature and mean annual precipitation is near-normal as well. These records cover a wide range of mean annual temperatures (from $-14^{\circ} \mathrm{C}$ to $+21^{\circ} \mathrm{C}$ ) and mean annual precipitation (from 256 to $2706 \mathrm{~mm}$ ). The wide range of biotic and abiotic conditions for measurements of $\mathrm{Rs}_{\mathrm{S}}$ flux and root contribution allowed analyzing the climate effect on these processes.

The main climatic factors driving root contribution to the $\mathrm{R}_{\mathrm{S}}$ flux in coniferous forests $(n=177)$ are mean annual precipitation, precipitation during the period with mean daily temperatures above 5 and $10^{\circ} \mathrm{C}$, and hydro-thermal conditions during these period, as well as duration of the period with temperature above $5^{\circ} \mathrm{C}$ and wetting conditions of the site:

[10] $\quad \mathrm{R}_{\mathrm{A} \%}=213.5066+0.0656 \times \mathrm{MAP}+0.1202 \times\left(\mathrm{P} \_5\right)-0.1460 \times\left(\mathrm{P} \_10\right)-61.4519 \times($ HTC_5 $)+$ $47.9206 \times($ HTC_10 $)+15.1405 \times(\operatorname{IndW})-51.6911 \times \ln ($ D_5 $)+46.9435 \times \ln ($ HTC_5 $)-$

$$
20.8020 \times \ln \left(\text { HTC_10), } \quad \mathrm{R}^{2}=0.35, \mathrm{p}<0.01\right.
$$

Deciduous forests root contribution $(\mathrm{n}=86)$ depends on accumulated temperatures during a period with temperature above 5 and $10^{\circ} \mathrm{C}$, and amount of precipitation during these periods:

[11] $\quad \mathrm{R}_{\mathrm{A} \%}=-408.392-0.070 \times($ SumT_5 $)+0.047 \times($ SumT_10 $)+98.140 \times \ln \left(\mathrm{P} \_5\right)-$

$$
29.509 \times \ln \left(\mathrm{P} \_10\right)+81.471 \times \ln (\operatorname{IndW}), \quad \mathrm{R}^{2}=0.22, \mathrm{p}<0.05
$$




\subsection{Heterotrophic soil respiration flux}

In order to estimate heterotrophic soil respiration $\left(\mathrm{R}_{\mathrm{H}}\right)$, the difference between annual total and autotrophic respiration was calculated, with application of correction coefficients by region, zone and vegetation type. The intersection of all involved datasets (soil, forest and climate maps) was used as a simulation unit. The finest resolution of the simulation units was $1 \mathrm{~km}$.

The annual mean soil efflux is defined at $3490 \mathrm{Tg} \mathrm{C} \mathrm{yr}^{-1}$, of which $\mathrm{R}_{\mathrm{A}}$ comprise $51.4 \%$ and $\mathrm{R}_{\mathrm{H}}-48.6 \%$ (Table 5). $\mathrm{R}_{\mathrm{H}}$ is defined at $1688 \mathrm{Tg} \mathrm{C} \mathrm{yr}^{-1}$ or $206 \mathrm{~g} \mathrm{C} \mathrm{m}^{-2} \mathrm{yr}^{-1}$ with an evident zonal gradient. Across both European and Asian parts $\mathrm{R}_{\mathrm{H}}$ increases from tundra (183-187 g C $\mathrm{m}^{-2} \mathrm{yr}^{-1}$ ) to temperate forests and steppe (maximum 283-378 $\mathrm{g} \mathrm{C} \mathrm{m}^{-2} \mathrm{yr}^{-1}$ ) and slightly declined to the semi-desert and desert zones. Interannual variability of $\mathrm{R}_{\mathrm{H}}$ for the entire country is not high ( $5 \%$ ) but is substantially higher (up to $23 \%$ ) by individual zones and regions. $\mathrm{R}_{\mathrm{H}}$ was higher in 1996-2005 compared to the long term average (Fig. 2). $\mathrm{R}_{\mathrm{H}}$ varies from -6.8 up to $+13.9 \%$ (the average $+4.4 \%$ ) in European part of Russia and from -3.1 up to $+5.2 \%$ (average $+2.1 \%$ ) in Siberia. The most volatile is $\mathrm{R}_{\mathrm{H}}$ in forest steppe and steppe zone of European part. It varies from -16 up to $+22 \%$ from year to year around the long term average. Siberian south taiga is an only region which demonstrates a small decrease $(-0.6 \%)$ of $\mathrm{R}_{\mathrm{H}}$ due to higher dryness of climate.

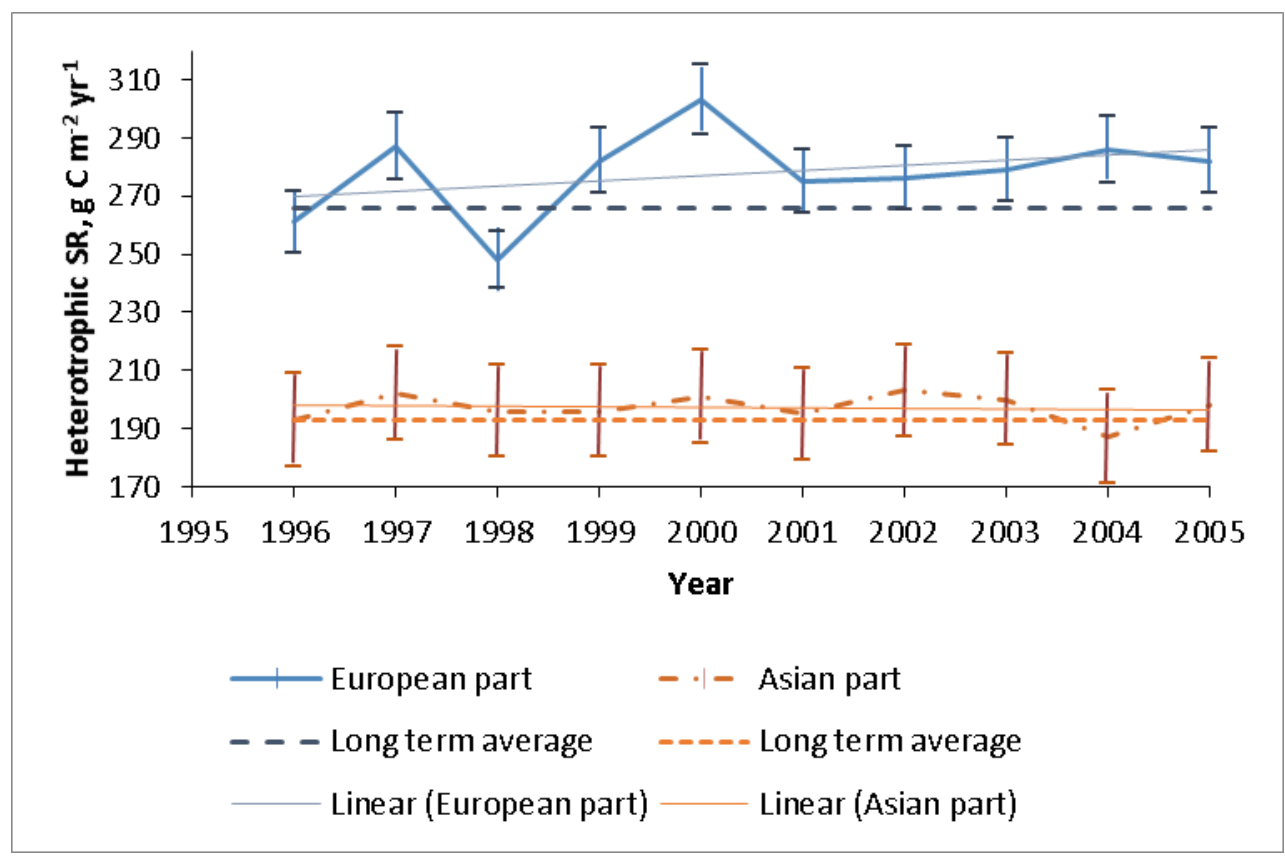

Fig.2. Dynamics of heterotrophic soil respiration 1996-2005. Bars indicate uncertainty of annual average values 
Table 5.

Soil respiration of Russian forested area and its contribution to carbon budget

\begin{tabular}{|c|c|c|c|c|c|c|c|c|}
\hline \multirow[b]{2}{*}{ Region/Zone } & \multirow[b]{2}{*}{$\begin{array}{l}\text { Area, } \\
10^{6} \\
\text { ha }\end{array}$} & \multirow{2}{*}{$\begin{array}{l}\mathrm{S}_{\mathrm{R}} \\
\mathrm{g} \mathrm{C} \\
\mathrm{m}^{-2} \\
\mathrm{yr}^{-1}\end{array}$} & \multirow{2}{*}{$\begin{array}{l}\mathrm{S}_{\mathrm{A}} \\
\mathrm{g} \mathrm{C} \\
\mathrm{m}^{-2} \\
\mathrm{yr}^{-1}\end{array}$} & \multicolumn{3}{|c|}{ Heterotrophic soil respiration } & \multirow{2}{*}{$\begin{array}{c}\text { Ratio } \\
\text { Rs/NPP, } \\
\%\end{array}$} & \multirow{2}{*}{$\begin{array}{l}{ }^{*} \mathrm{NECB}, \\
\mathrm{g} \mathrm{C} \mathrm{m}^{-2} \\
\mathrm{yr}^{-1}\end{array}$} \\
\hline & & & & $\begin{array}{c}\text { average, } \\
\text { g C m}^{-2} \\
\mathrm{yr}^{-1}\end{array}$ & $\begin{array}{l}\text { total, } \\
\text { Tg C } \\
\mathrm{yr}^{-1}\end{array}$ & $\begin{array}{l}\text { range } \\
(1996- \\
2005 y r), \\
\text { Tg C yr }^{-1}\end{array}$ & & \\
\hline \multicolumn{9}{|c|}{ European part } \\
\hline Tundra & 4.0 & 377 & 194 & 183 & 7.4 & $6.0-9.1$ & 62 & 96 \\
\hline $\begin{array}{l}\text { Forest tundra, } \\
\text { northern \& } \\
\text { sparse taiga }\end{array}$ & 34.2 & 338 & 173 & 165 & 56.6 & $51.3-64.4$ & 54 & 111 \\
\hline Middle Taiga & 56.8 & 465 & 240 & 225 & 128.2 & $\begin{array}{l}124.1- \\
142.1\end{array}$ & 56 & 117 \\
\hline Southern Taiga & 55.9 & 572 & 299 & 273 & 152.8 & $\begin{array}{l}146.3- \\
171.9\end{array}$ & 50 & 185 \\
\hline $\begin{array}{l}\text { Temperate } \\
\text { forests }\end{array}$ & 11.7 & 643 & 353 & 290 & 34.1 & 31.1-38.5 & 44 & 211 \\
\hline Steppe & 5.3 & 856 & 478 & 378 & 20.1 & $16.4-23.6$ & 63 & 81 \\
\hline $\begin{array}{l}\text { Desert \& semi- } \\
\text { desert }\end{array}$ & 0.2 & 734 & 423 & 311 & 0.9 & $0.8-0.9$ & 64 & 34 \\
\hline Subtotal & 168.1 & 498 & 260 & 238 & 400.1 & $\begin{array}{c}376.0- \\
450.5\end{array}$ & 53 & 143 \\
\hline \multicolumn{9}{|c|}{ Asian part } \\
\hline Tundra & 16.4 & 371 & 184 & 187 & 30.7 & 28.1-35.5 & 83 & 24 \\
\hline $\begin{array}{l}\text { Forest tundra, } \\
\text { northern \& } \\
\text { sparse taiga }\end{array}$ & 106.5 & 331 & 167 & 164 & 175.5 & $\begin{array}{l}166.7- \\
197.3\end{array}$ & 77 & 29 \\
\hline Middle Taiga & 410.9 & 388 & 198 & 190 & 782.7 & $\begin{array}{l}769.7- \\
832.6\end{array}$ & 69 & 47 \\
\hline Southern Taiga & 91.4 & 513 & 267 & 246 & 225.5 & $\begin{array}{l}209.7- \\
241.2\end{array}$ & 65 & 70 \\
\hline $\begin{array}{l}\text { Temperate } \\
\text { forests }\end{array}$ & 16.3 & 605 & 322 & 283 & 46.2 & $42.2-51.3$ & 69 & 53 \\
\hline Steppe & 10.7 & 516 & 273 & 243 & 26.1 & 24.9-29.2 & 66 & 45 \\
\hline $\begin{array}{l}\text { Desert \& semi- } \\
\text { desert }\end{array}$ & 0.6 & 360 & 193 & 167 & 1.1 & $1.0-1.3$ & 46 & 38 \\
\hline Subtotal & 652.8 & 402 & 205 & 197 & 1287.8 & $\begin{array}{l}1241.9- \\
1388.7\end{array}$ & 70 & 47 \\
\hline Total Russia & 820.9 & 423 & 217 & 206 & 1687.9 & $\begin{array}{c}1617.9- \\
1839.1 \\
\end{array}$ & 65 & 66 \\
\hline
\end{tabular}

\section{* Data from Shvidenko and Schepaschenko (2014)}

When compared with forest NPP (Shvidenko et al., 2008), the ratio of $\mathrm{R}_{\mathrm{H}} / \mathrm{NPP}$ is substantially higher in Asian (0.70) than European (0.53) Russia with similar zonal gradients. The main reason of this we see in principal differences of the growth conditions in these large parts of Russia. An absolute majority of Asian forests are growing on permafrost and, excluding monsoon regions of the Far East, under very limited amount of summer precipitation. 
Spatial distribution of $\mathrm{R}_{\mathrm{H}}$ is presented in the Fig. 3. The original spatial resolution of the map is $1 \mathrm{~km}^{2}$. The map is available online at http://Russia.geo-wiki.org.

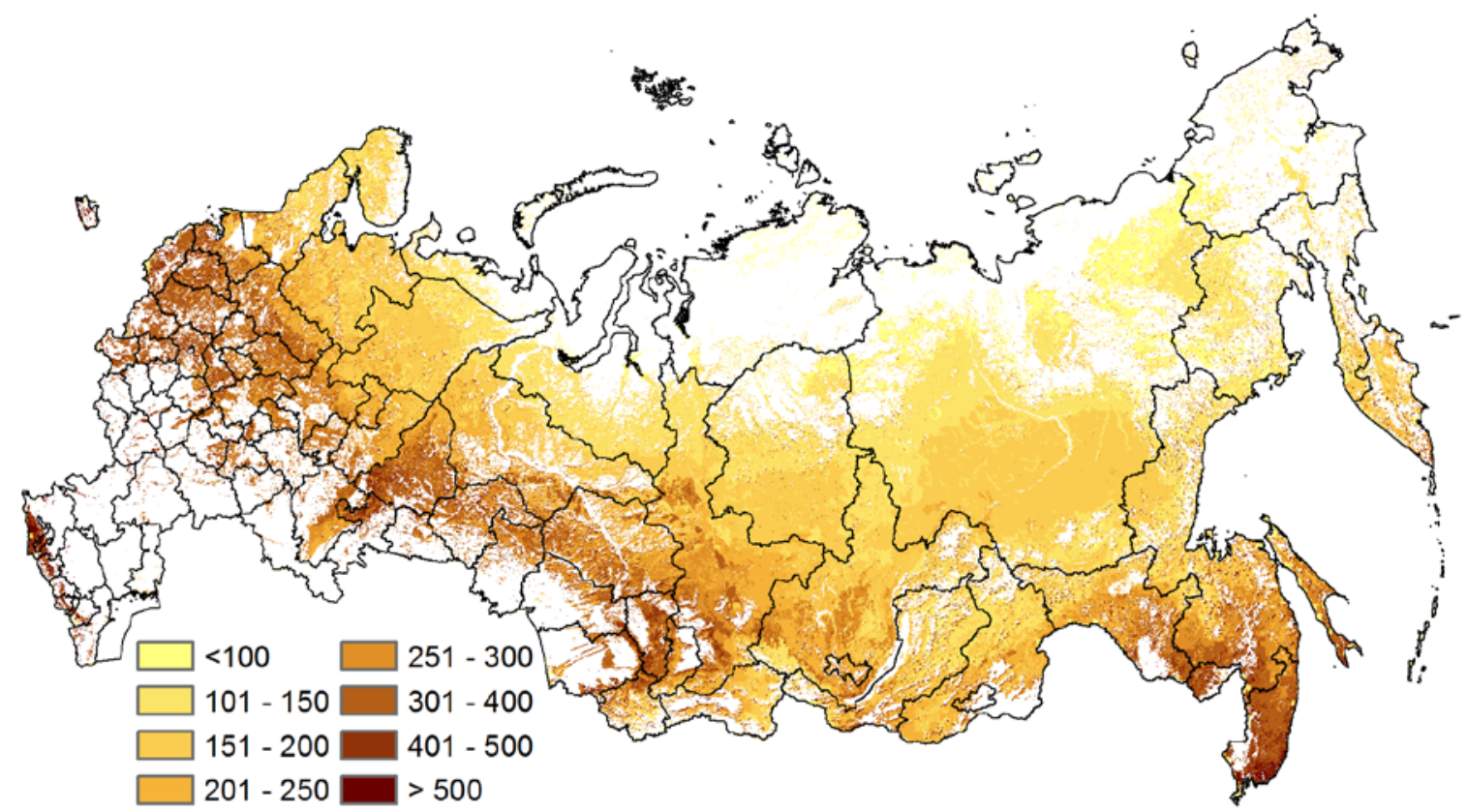

Fig. 3. Map of heterotrophic soil respiration in Russian forests.

\section{Discussion}

\subsection{Forest soil carbon pool}

The major part of Russian forests are represented by boreal ecosystems (92\% of the total forested area) that generally contain more carbon than the temperate forest biome and have the total carbon density close to that in tropical forests (238 Mg C ha') (Pan et al., 2011). About one-fourth of boreal forest carbon is stored in vegetation. The rest, $75 \%$, is in the forest soil. Carbon accumulation in boreal forest soils is driven by slow decomposition rates, in part due to a short vegetation period and acidity of soils under conifer forests. Both of these factors can limit decomposition with the high soil carbon content being important for the carbon cycle, as management activities disturbing boreal forest soils can increase carbon emission to the atmosphere (Gorte, 2009).

Russian forest estimates of carbon stock of the $\mathrm{O}$ horizon previously reported vary substantially, from 0.72 (Chestnych et al., 2007) to $1.80 \mathrm{~kg} \mathrm{C} \mathrm{m}^{-2}$ (Alexeyev \& Birdsey, 1998). Our estimate on average is $1.01 \mathrm{~kg} \mathrm{C} \mathrm{m}^{-2}$ and varies from $0.39-0.48 \mathrm{~kg} \mathrm{C} \mathrm{m}^{-2}$ (forested areas in semi-desert zone) to $1.26 \mathrm{~kg} \mathrm{C} \mathrm{m}^{-2}$ (for broad-leaved forests of the Far East).

Our average estimate of the forest SOC pool density $\left(17.6 \mathrm{~kg} \mathrm{~m}^{-2}\right)$ is close to the average within the range of other author's estimations: 9.6-20.3 $\mathrm{kg} \mathrm{C} \mathrm{m}^{-2}$ (Alexeyev \& Birdsey, 1998; Rozhkov et al., 1996; Zamolodchikov et al., 2005; Chestnych et al., 2004). Major reasons of such variability are different information bases and methods of the estimation, considering or excluding disturbances etc.

Based on analysis of the calculation scheme and specifics of information we did not recognize any substantial biases. An application of an approach mentioned above has led to a conclusion that the total stock of SOC in soil of Russian forests is estimated within $\pm 5 \%$ (CI 0.9). This estimate includes a number of expert judgments. 


\subsection{Heterotrophic soil respiration flux}

Our estimate of $\mathrm{R}_{\mathrm{H}}$ (206 $\mathrm{g} \mathrm{C} \mathrm{m}^{-2} \mathrm{yr}^{-1}$ ) is higher than other published results for Russian forests. For example, Nilsson et al. (2000) reported $179 \mathrm{~g} \mathrm{C} \mathrm{m}^{-2} \mathrm{yr}^{-1}$, Kurganova (2003) - 171 $\mathrm{g} \mathrm{C} \mathrm{m}^{-2} \mathrm{yr}^{-1}$, Golubyatnikov (2011) - around $160 \mathrm{~g} \mathrm{C} \mathrm{m}^{-2} \mathrm{yr}^{-1}$.

Several reasons contributed to these differences. To a substantial extent, this is the result of different approaches that were used in the assessments and the use of different information, particularly the amount of in situ measurements. All the above studies did not consider the impacts of a full set of factors (e.g. the impact of weather condition for the year of measurement, etc.) on soil respiration. Our estimate was based on the specificity of different ensembles of soil groups - forest type - land-use specifics - disturbances response to the climatic conditions whereas Nilsson et al. (2000) calculated $\mathrm{R}_{\mathrm{H}}$ based on the mean daily $\mathrm{CO}_{2}$ emission for an individual soil types and number of days with mean daily temperature above $0^{\circ} \mathrm{C}$. Kurganova (2003) used average annual carbon dioxide flux by soil type and different vegetation classes as well. Golubyatnikov (2011) used a terrestrial carbon cycle model calibrated to results obtained in other studies.

The calculated annual $\mathrm{R}_{\mathrm{H}}$ across the territory of Russia closely depends on average temperature of frost free (average daily temperature above $0^{\circ} \mathrm{C}$ ) season $(\mathrm{R}=0.86)$ and duration of frost free period ( $\mathrm{R}=0.83$ ) (Fig. 4). The main factor which controls $\mathrm{R}_{\mathrm{H}}$ in the Asian part of Russia is duration of warm period $(\mathrm{R}=0.86)$ while in the European part both of the above factors play an important role (for annual average for zones of European part of country average for $\mathrm{T}>0 \mathrm{R}=0.89$, for $\mathrm{D}>0 \mathrm{R}=0.84$ ).
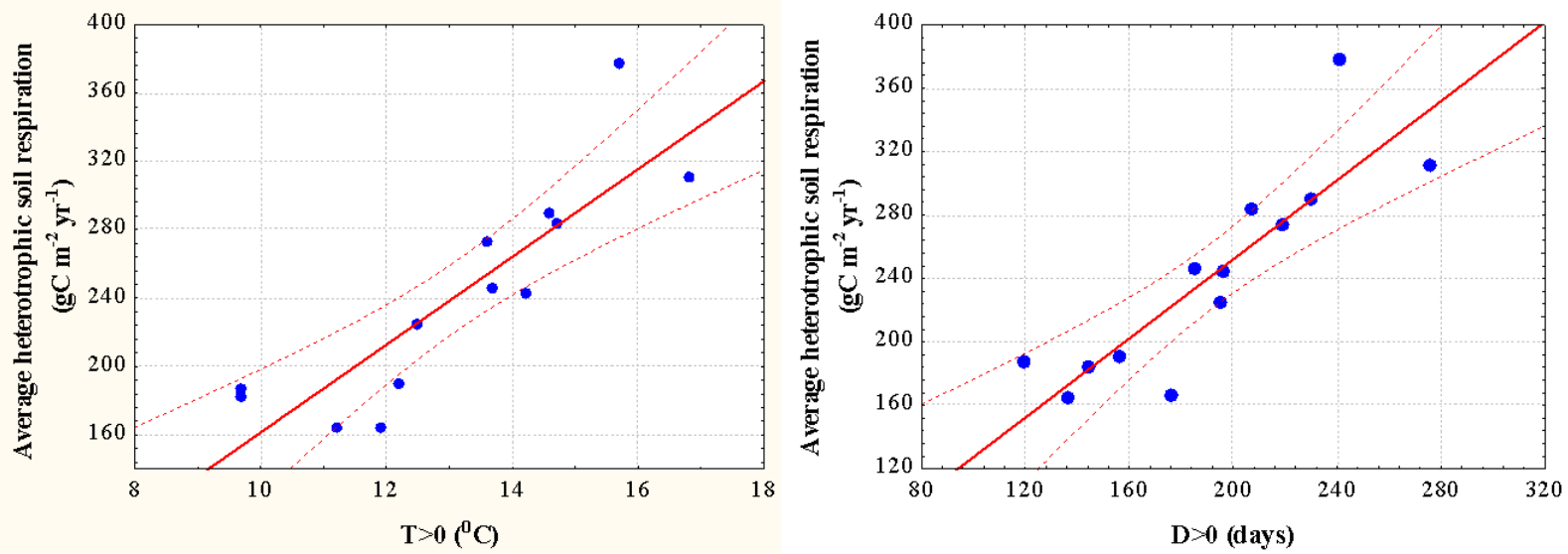

Fig. 4. Dependence of annual $\mathrm{R}_{\mathrm{H}}$ on average temperature and duration of frost free period: $\mathrm{T}>0\left({ }^{0} \mathrm{C}\right)$ - sum of degree days during the period with temperature above $0^{0} \mathrm{C}$; $\mathrm{D}>0$ (days) numbers of days with temperature above $0^{\circ} \mathrm{C}$.

No correlations were found of $\mathrm{R}_{\mathrm{H}}$ with size of the average soil organic matter pool in forests by individual zones and soil groups. The uncertainty of annual average of soil heterotrophic respiration for all Russian forests was estimated at 8\% (here and below CI is 0.9). This estimate also contains expert judgments. We calculated the interannual variability of $\mathrm{R}_{\mathrm{H}}$ for the decade from 1996 - 2005 by bioclimatic zones separately for European and Asian parts. This was typically in range of 5-11\% with three exclusions (15-18\%) for regions with relatively small area of forests but which grow in substantially different conditions within the region (tundra and steppe in European and desert zone in Asian parts). The interannual variability of the $\mathrm{R}_{\mathrm{H}}$ for the entire country was $4.1 \%$. 


\subsection{Contribution of soil respiration to the carbon budget of Russian forests}

Overall, the heterotrophic carbon dioxide efflux is about 65\% of NPP of forest ecosystems on the territory of Russia; additionally about 7\% of NPP is released annually through dead wood decomposition and about $5 \%$ is lost due to wild fire emission and insect impacts (Fig. $5)$.

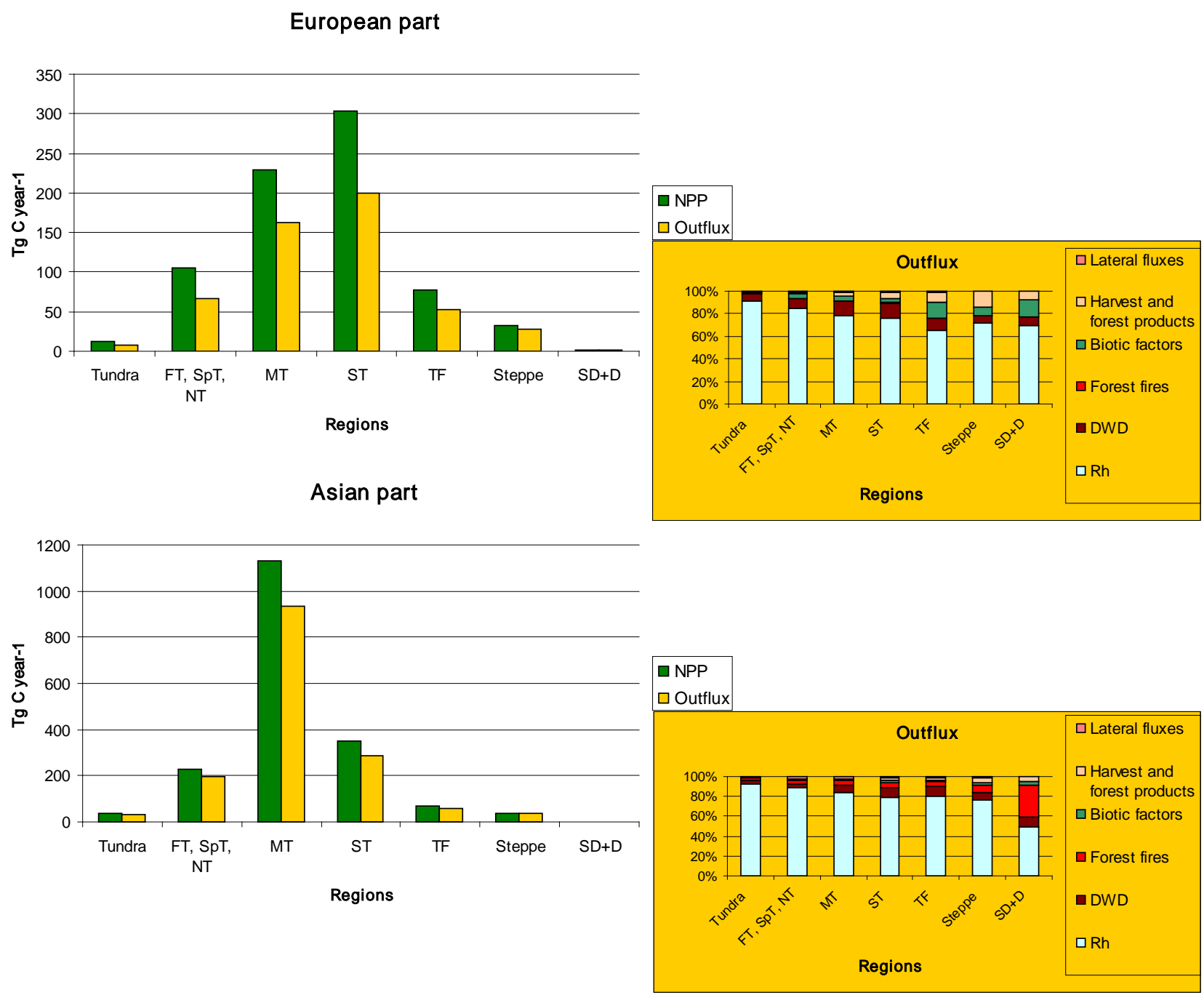

Fig. 5. Contribution of $\mathrm{R}_{\mathrm{H}}$ to carbon budget of Russian forests (average for 2007-2009).

Carbon fluxes besides $\mathrm{R}_{\mathrm{H}}$ are taken from (Shvidenko, Schepaschenko, 2014)

Thus, about 23\% of the NPP is annually accumulated in the Russian forests. The results received by ensembles of DGVMs and inverse models showed very close results: during the

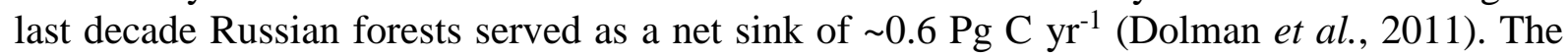
last supports our assumption of absence of systematic bias in our estimation of $\mathrm{R}_{\mathrm{H}}$.

The reported results on $\mathrm{R}_{\mathrm{H}}$ and carbon budget of forest ecosystems of different bioclimatic zones in European and Asian part of Russia are consistent with experimental assessments made in different regions of the country (Table 6).

Soil organic matter is a dynamic substance and, by the impacts on the carbon cycling, the turnover of soil organic matter is more significant than the size of soil organic matter stock. Most often, the turnover is quantified as the element mean residence time (MRT) that is defined as an average time is required to completely renew the content of the pool at steady 
state (Six \& Jastrow, 2002). Primary production and soil microbial activity are recognized as the overarching biological processes governing the fluxes in and out of soil organic matter pools and, hence, they govern soil organic matter turnover. Balance between these two processes are controlled by a complex array of biotic and abiotic interactions, with analysis indicating the dominant drivers can vary among different ecosystems (Chen et al., 2013). Thus, MRT is a property of the interactions between soil organic carbon and surrounding environment.

Table 6.

Measured Net Primary Production (NPP), Heterotrophic Respiration $\left(\mathrm{R}_{\mathrm{H}}\right)$ and Net Ecosystem Production (NEP) for forest ecosystems of Russia, g C m² $\mathrm{yr}^{-1}$

\begin{tabular}{|c|c|c|c|c|c|}
\hline Zone & Region/Forest type & NPP & RH & NEP & References \\
\hline \multicolumn{6}{|c|}{ European part } \\
\hline \multirow{3}{*}{$\begin{array}{l}\text { Forest tundra, } \\
\text { northern \& sparse } \\
\text { taiga }\end{array}$} & $\begin{array}{l}\text { Komi } \\
\text { Spruce forests }\end{array}$ & $372 \pm 26 * *$ & $345^{*}$ & $20-30$ & $\begin{array}{l}\text { Bobkova, } \\
\text { Tuzhilkina, } 2006\end{array}$ \\
\hline & $\begin{array}{l}\text { Komi } \\
\text { Scots pine forests }\end{array}$ & $203 \pm 54$ & & & Bobkova, 2005 \\
\hline & $\begin{array}{l}\text { Karelia } \\
\text { Scots pine forests }\end{array}$ & $252 \pm 27$ & $132 \pm 9$ & 120 & $\begin{array}{l}\text { Sinkevich et al., } \\
2009\end{array}$ \\
\hline \multirow[t]{3}{*}{ Middle Taiga } & $\begin{array}{l}\text { Komi } \\
\text { Spruce forests }\end{array}$ & $355 \pm 12$ & 230 & $125 \pm 41^{*}$ & $\begin{array}{l}\text { Bobkova, } \\
\text { Tuzhilkina, 2006; }\end{array}$ \\
\hline & $\begin{array}{l}\text { Komi } \\
\text { Scots pine forests }\end{array}$ & $257 \pm 43$ & 144 & $113^{*}$ & $\begin{array}{l}\text { Bobkova, Osipov, } \\
2012\end{array}$ \\
\hline & $\begin{array}{l}\text { Karelia } \\
\text { Scots pine forests }\end{array}$ & $331 \pm 75$ & $215 \pm 35$ & $116^{*}$ & $\begin{array}{l}\text { Sinkevich et al., } \\
2009\end{array}$ \\
\hline Southern Taiga & $\begin{array}{l}\text { Leningrad oblast } \\
\text { Scots pine, spruce, aspen } \\
\text { and birch forests }\end{array}$ & 441 & 244 & 197 & Chan, 2012 \\
\hline Temperate forests & $\begin{array}{l}\text { Orel oblast } \\
\text { Oak forests }\end{array}$ & $318 \pm 29$ & $180^{*}$ & $140 \pm 38$ & $\begin{array}{l}\text { Tarankov, } \\
\text { Stepochkin, } 2005\end{array}$ \\
\hline \multicolumn{6}{|c|}{ Asian part } \\
\hline \multirow{2}{*}{$\begin{array}{l}\text { Forest tundra, } \\
\text { northern \& sparse } \\
\text { taiga }\end{array}$} & $\begin{array}{l}\text { Central Siberia } \\
\text { Larch and spruce forests }\end{array}$ & $199 \pm 50$ & $141 \pm 17$ & 59 & Vedrova, 2005 \\
\hline & $\begin{array}{l}\text { Eastern Siberia } \\
\text { Larch forests }\end{array}$ & 246 & 156 & 72 & $\begin{array}{l}\text { Schepaschenko et } \\
\text { al., } 2008\end{array}$ \\
\hline Middle Taiga & $\begin{array}{l}\text { Central Siberia } \\
\text { Scots Pine forests }\end{array}$ & $270 \pm 97$ & $229 \pm 43$ & 42 & Trefilova, 2006 \\
\hline \multirow[t]{2}{*}{ Southern Taiga } & \multirow{2}{*}{$\begin{array}{l}\text { Central Siberia } \\
\text { Light and dark } \\
\text { coniferous and deciduous } \\
\text { forests }\end{array}$} & $389 \pm 50$ & $261 \pm 94$ & 128 & Vedrova, 2005; \\
\hline & & $475 \pm 51$ & $394 \pm 40$ & 81 & Koshurnikova, 2007 \\
\hline
\end{tabular}

Experimental data show that even under the annual input of fresh plant material into soil contribution of old soil carbon in heterotrophic soil respiration flux exceeds $60 \%$ (Kvitkina et al., 2010). Turnover time basically depends on temperature and temperature growth increases contribution of old soil carbon to total heterotrophic respiration flux. Reported turnover time of young soil carbon varies from 14 to 96 years, and for old soil carbon the average MRT is from 30 to 293 years (Kvitkina et al., 2010). MRT of total soil organic carbon in forest ecosystems estimated as 22-1005 years depending on used methodology (Six \& Jastrow, 2002). 
The average MRT for the soil organic matter of forests of the European and Asian parts of Russia is estimated at 68 and 87 years, respectively. The turnover time differs by the bioclimatic zones (Fig. 6). The main reason of such differences are likely climatic conditions which influence decomposition activity of microbes. This is supported by data of Figure 6, where soils by the zones of the Asian part have longer turnover time than those of European Russia. The only exclusion is observed for tundra and temperate zones for which differences in hydrological regimes of European and Asian parts are substantial.

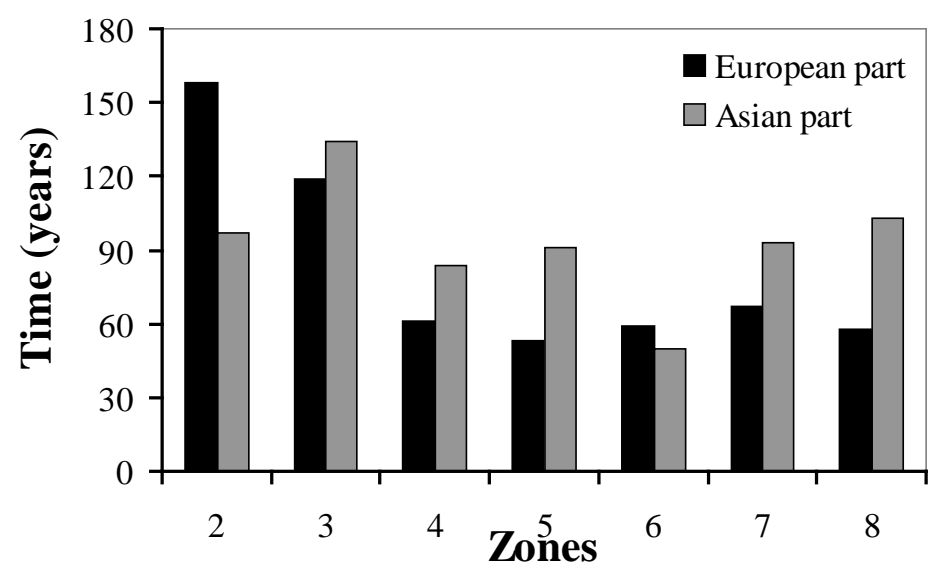

Fig. 6. Turnover time (MRT) of soil organic matter in forest ecosystems of different zones: 2 - Tundra; 3 - Forest tundra, northern \& sparse taiga; 4 - Middle Taiga; 5 - Southern Taiga; 6 - Temperate forests; 7 - Steppe; 8 - Desert \& semi-desert.

Chen with coauthors (2013) have calculated global MRT equal to 54-65 years for soil organic carbon in the topsoil $(0-20 \mathrm{~cm})$ in the latitude zone of $\mathrm{N} 75^{0}-\mathrm{N} 45^{0}$. Our estimation is higher probably because we take into account carbon stock in $1 \mathrm{~m}$ soil depth that contains more old carbon with the longer turnover time.

Forests of the European part of the country provide about $44 \%$ of total annual Net Ecosystem Carbon Balance in Russian forests (Table 5) despite the fact that this territory contains only about $21 \%$ of the total forested area. Annual carbon sink per unit area in forest ecosystems of Asian part is 2.5 - 3.0 times lower in comparison with forests of European part of country. Based on experimental data by these regions, we hypothesize that European and Asian forests have a different structure of allocation of accumulated carbon: while in European forests the main reservoir for carbon allocation is tree live biomass due to the higher tree stands productivity under the milder climatic conditions, forests in Siberia and Far East regions mostly accumulate carbon in the soil due to the lower rate of litter decomposition.

According to Vedrova (2005) carbon sink to the tree live biomass make up only 9\% of NEP in northern taiga of Central Siberia. The major part of annual carbon is accumulated in live forest floor and phytodetritus. In European part of Russia the annual litterfall makes up $108 \pm 44-203 \pm 38 \mathrm{~g} \mathrm{C} \mathrm{m}^{-2}$ in the northern taiga and $183 \pm 26 \mathrm{~g} \mathrm{C} \mathrm{m}^{-2}$ in the temperate forest zone (Molchanov, 1971). This litterfall input is almost equal to the estimated annual heterotrophic respiration flux from soils in the northern taiga $\left(165 \mathrm{~g} \mathrm{C} \mathrm{m}^{-2}\right)$ and even lower than respiration of temperate forests soils $\left(290 \mathrm{~g} \mathrm{C} \mathrm{m}^{-2}\right)$. It means that soils of these forests do not accumulate carbon due to the negative balance between litterfall input and decomposition rate of soil organic matter. Annual net stem live biomass production in these northern taiga forests make up from $135 \pm 92 \mathrm{~g} \mathrm{C} \mathrm{m}^{-2} \mathrm{yr}^{-1}$ in spruce forests to $243 \pm 100 \mathrm{~g} \mathrm{C} \mathrm{m}^{-2} \mathrm{yr}^{-1}$ in pine forests of different age. In temperate oak forests it reaches $185 \pm 65 \mathrm{~g} \mathrm{C} \mathrm{m}^{-2} \mathrm{yr}^{-1}$ for age range 
at 10-220 years (Molchanov, 1971). This is close to the reported above values of annual average carbon sequestration in these zones. Thus one can conclude that major part of the carbon sink in these ecosystems is likely tree live biomass in contrast to the forests of the Asian part of country.

The assumption that the structure of carbon allocation is different for the European and Asian parts supposes different sustainability of accumulated carbon pools. Carbon accumulated in soil is more resistant because disturbances such as harvest and fires do not destroy this pool quickly. Certainly, disturbances can change conditions for soil organic matter decomposition but this process is long-term, in contrast to the live biomass pool that can be quickly removed by logging or fire. Thus the smaller annual carbon sink in the large Asian forests seems more persistent with respect to carbon sequestration.

\section{Conclusions}

The system of carbon stock accounting and estimation of respiration activity of forest soils described here allows for improvements over the previously reported results. The calculated SOC pool in Russian forests (limited to the top 1m depth) makes up 144.5 Pg C that is about $46 \%$ of the total SOC stock of terrestrial ecosystems of Russia (Schepaschenko et al., 2013). Mean annual heterotrophic soil respiration flux from Russian forests is estimated to be about $1688 \pm 135 \mathrm{Tg} \mathrm{C}$ year $^{-1}$, or about $1.2 \%$ of the total soil carbon storage in these lands. Expert analysis of "uncertainties of uncertainties" supports a high probability of this conclusion. If we add to $\mathrm{RH}$ the flux caused by decomposition of CWD ( 175 $\mathrm{Tg}_{\mathrm{C}}$ year $\left.{ }^{-1}\right)$, the total heterotrophic respiration of forests in Russia is estimated at $1863 \mathrm{Tg} \mathrm{C}_{\mathrm{year}}{ }^{-1}$.

Heterotrophic soil respiration over the country's forests makes up about $65 \%$ of NPP. The net balance between carbon sequestration and carbon release shows that the Russian forest

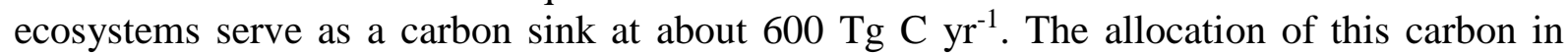
European and Asian parts of Russia is different. European Russian forests annually accumulate 2.5-3.0 times more carbon per unit area and the major pool of this accumulation is likely tree live biomass in contrast to Asian Russian forests, where low tree growth and lower rate of plant material decomposition provide preference for carbon accumulation in the soil and onground organic layer.

\section{Acknowledgments}

This research was partially supported by National Institute for Environmental Studies, Japan and by the European Community’s Framework Programme (FP7) via GEOCarbon (No 283080).

The authors gratefully acknowledge financial support from the Scholarship Council of the Scholarship Foundation of the Republic of Austria and Austrian Agency for International Cooperation in Education and Research (OeAD-GmbH), Centre for International Cooperation \& Mobility (ICM) granted to Liudmila Mukhortova (ZI: ICM-2010-00915). 


\section{References}

Alexeyev VA, Birdsey RA (1998) Carbon storage in forests and peatlands of Russia. Gen. Tech. Rep., NE-244, USDS For. Serv.

Amiro BD, MacPherson JI, Desjardins RL, Chen JM, Liu, J (2003) Post-fire carbon dioxide fluxes in the western Canadian boreal forest, evidence from towers, aircraft and remote sensing. Agricultural and Forest Meteorology, 115, 91-107. doi: 10.1016/S0168-1923(02)00170-3

Amiro BD, MacPherson JI, Desjardins RL (1999) BOREAS flight measurements of forestfire effects on carbon dioxide and energy fluxes. Agricultural and Forest Meteorology, 96, 199-208.

Bahn M, Rodeghiero M, Anderson-Dun M, et al. (2008) Soil respiration in European grasslands in relation to climate and assimilate supply. Ecosystems, 11, 1352-1367.

Bezkorovainaya IN, Ivanova GA, Tarasov PA (2005) Pyrogenic Transformation of Soils in Central Taiga Pine Forests of Krasnoyarsk Kray. Sibirsky ecologichescky zhurnal, 1, 143-152. [In Russian]

Bezkorovaynaya IN, Antonov GI, Ivanov VV, Semenyakin DA (2010) Biological activity of soils after thinning in Scots pine forests of Krasnoyarsk forest-steppe. Coniferous of boreal zone, XXVII(3-4), 238-342.

Birdsey RA, Heath LS (1995) Carbon changes in US forests. In: Productivity of America's Forests and Climate Change, General Technical Report RM-271 (ed Joyce LA), PP. 56-70, USDA Forest Service, Rocky Mountain Forest and Range Experiment Station, Fort Collins, CO.

Bobkova KS (2005) Biological productivity and components of carbon balance in young pine stands. Contemporary Problems of Ecology, 6, 30-37.

Bobkova KS, Tuzhilkina VV (2006) Carbon cycle in spruce ecosystems. Virgin spruce forest of North: biodiversity, structure, functions. St. Petersburg. Nauka. pp. 265-288.

Bobkova KS, Osipov AF (2012) Carbon cycling in System Phytocenosis-Soil in BilberrySfagnum Pine Forests of Middle Taiga (Republic of Komi). Contemporary Problems of Ecology, 2, 11-18.

Bond-Lamberty BP, Thomson AM (2010) A Global Database of Soil Respiration Data, Version 1.0. Data set. Available on-line [http://daac.ornl.gov] from Oak Ridge National Laboratory Distributed Active Archive Center, Oak Ridge, Tennessee, U.S.A. doi:10.3334/ORNLDAAC/984

Bond-Lamberty B, Wang CK, Gower ST (2004) A global relationship between the heterotrophic and autotrophic components of soil respiration? Global Change Biology, 10(10), 1756-1766.

Boone RD, Nadelhoffer KJ, Canary JD, Kaye JP (1998) Roots exert a strong influence on the temperature sensitivityof soil respiration. Nature, 396, 570-572

Brown S, Swingl JR, Tenison RH, Prance GT, Myers N (2002) Changes in the use and managements of forests for abating carbon emission: issues and challenges under the Kyoto Protocol. Philos. Trans. R. Soc. Lond. A, 360, 1593-1605. doi: 10.1098/rsta.2002.1021.

Burke AR, Zepp GR, Tarr AM, Miller WL, Stocks BJ (1997) Effect of fire on soilatmosphere exchange of methane and carbon dioxide in Canadian boreal forest sites. Journal of Geophysical Research, 102, 29289-29300. doi:10.1029/97JD01331.

Certini G (2005) Effects of fire on properties of forest soils: a review. Oecologia, 143, 1-10.

Ceulemans, R., I. Impens and V. Steenackers. 1987. Variations in photosynthetic, anatomical, and enzymatic leaf traits and correlations with growth in recently selected Populus hybrids. Canadian Journal of Forest Research, 17, 273--283. 
Chan TTN (2012) Carbon pools and fluxes in Okhtinsk forest massif (Leningrad area). Abstract of PhD thesis. St.Peterburg, Russia.

Chen S, Huang Y, Zou J, Shi Y (2013) Mean residence time of global topsoil organic carbon depends on temperature, precipitation and soil nitrogen. Global and Planetary Change, 100, 99-108.

Chestnykh OV, Lyzhin VA, Koksharov AV (2007) Carbon stock in forest litter of Russia. Contemporary Problems of Ecology, 6, 114-121.

Chestnykh OV, Zamolodchikov DG, Utkin AI (2004) Total stock of biological carbon and nitrogen in soil of forest fund of Russia. Contemporary Problems of Ecology, 4, 30-42.

Concilio A, Ma S, Ryu S-R, North M, Chen J (2006) Soil respiration response to experimental disturbances over 3 years. Forest Ecology and Management, 228, 82-90.

Dixon RK, Brown S, Houghton RA, Solomon AM, Trexler MC, Wisniewski J (1994) Carbon pools and flux of global forest ecosystems. Science, 263,185-190.

Dolman AJ, Shvidenko A, Schepaschenko D, et al., (2012) An estimate of the terrestrial carbon budget of Russia using inventory-based, eddy covariance and inversion methods. Biogeosciences, 9, 5323-5340.

Edmonds RL, Marra JL, Barg AK, Sparks GB (2000) Influence of Forest Harvesting on Soil Organisms and Decomposition in Western Washington. USDA Forest Service Gen. Tech. Rep. PSW-GTR-178, 53-72.

Enting IG, Rayner PJ, Ciais P (2012) Carbon Cycle Uncertainty in REgional Carbon Cycle Assessment and Processes (RECCAP). Biogeoscience, 9, 2889-2904

Ewel KC, Cropper WJr, Gholz HL (1987) Soil CO, evolution in Florida slash pine plantations. I. Changes through time. Canadian Journal of Forest Research, 17, 325-329.

Fang C, Moncrieff JB, Gholz HL, Clark K (1998) Soil CO2 efflux and its spatial variation in a Florida slash pine plantation. Plant and Soil, 205, 135-146.

FAO (2006) Guidelines for soil description. FAO, Rome. 109 p. ISBN 92-5-105521-1.

FAO (2009) State of the world forests. Food and Agriculture Organization of the United Nations, Rome, 177 pp.

Feiziene D, Feiza V, Vaideliene A, Povilaitis V, Antanaitis S (2010) Soil surface carbon dioxide exchange rate as affected by soil texture, different long-term tillage application and weather. Zemdirbyste=Agriculture, 97(3), 25-42.

Fearnside PM, Barbosa RI (1998) Soil carbon changes from convertion of forest to pasture in Brasilian Amazonia. Forest Ecology and Management, 108, 147-166.

Gates DM (1980) Biophysical Ecology. Springer-Verlag. N. Y.

Gaumont-Guay D, Black TA, McCaughey H, Barr AG, Krishnan P, Jassal RS, Nesic Z (2009) Soil CO2 efflux in contrasting boreal deciduous and coniferous stands and its contribution to the ecosystem carbon balance. Global Change Biology, 15, 1302-1319.

Goldammer JG, Furyaev VV (eds.) (1996) Fire in Ecosystems of Boreal Eurasia. Kluwer Academic Publishers. ISBN 0-7923-4137-6.

Golubyatnikov LL (2011) Model estimation of carbon flux from the soil: Russia case study. Geophysical Res. Abstracts. 13, EGU2011-1898. EGU General Assembly 2011.

Gorte RW (2009) Carbon sequestration in forests. Congressional Res. Serv. Rep. for Congress, USA. Available on http://www.fas.org/sgp/crs/misc/RL31432.pdf [assessed 19 May 2012].

Hanson PJ, Wullschleger SD, Bohlman SA, Todd DE (1993) Seasonal and topographic pattern of forest floor CO2 efflux from an upland oak forest. Tree Physiology, 13, 115.

Hely C, Bergeron Y, Flannigan WD (2000) Coarse woody debris in the southeastern Canadian boreal forest: composition and load variations in response to stand replacement. Canadian Journal of Forest Research, 30, 674- 687. 
Hendrickson OQ, Chatarpaul L and Burgess D (1989) Nutrient cycling following whole-tree and conventional harvest in northern mixed forest. Canadian Journal of Forest Research, 19, 725-735.

Hibbard KA, Law BE, Reichstein M, Sulzman J (2005) An analysis of soil respiration across northern hemisphere temperate ecosystems. Biogeochemistry, 73, 29-70.

Hicke JA, Asner GP, Kasischke ES, et al. (2003) Postfire response of North American boreal forest net primary productivity analyzed with satellite observations. Global Change Biology, 9, 1145-1157.

Hogberg P, Nordgren A, Buchmann N, et al. (2001) Large-scale forest girdling shows that current photosynthesis drives soil respiration. Nature, 411, 789-792.

IUSS Working Group WRB (2006) World reference base for soil resources 2006. World Soil Resources Reports No. 103. FAO, Rome. Available at: ftp://ftp.fao.org/agl/agll/docs/wsrr103e.pdf

Kirschbaum MUF (1995) The temperature dependence of soil organic matter decomposition, and the effect of global warming on soil organic C storage. Soil Biology \& Biochemistry, 27, 753-760.

Komarov AS, Kubasova TS (2007) Modeling organic matter dynamics in conifer-broadleaf forests in different site types upon fires: A computational experiment. Biology Bulletin. Russian Academy of Science, 34(4), 408-416. DOI: 10.1134/S1062359007040139.

Koshurnikova NN (2007) Carbon budget in dark-coniferous forests of southern taiga. Abstract of PhD thesis. Krasnoyarsk, Russia.

Kurganova I (2003) Carbon Dioxide Emissions from Soils of Russian Terrestrial Ecosystems. Interim Rep. IR-02-070. International Institute for Applied System Analysis, Laxenburg, Austria.

Kurganova IN (2010) Carbon dioxide emission and balance in terrestrial ecosystems of Russia. Moscow. MSU.

Kvitkina AK, Larionova AA, Ponkratov IN, Sapronov DV, Bykhovetz SS (2010) Pool identification and determinantion of constants for decomposition of old and young carbon in leached chernozem. Biosphere function of soil cover. Proceedings of scientific conference. Puschino. SYNCHROBOOK. pp.145-147.

La Scala Jr N, Marques Jr J, Pereita GT , Corá JE (2000) Short-term temporal changes in the spatial variability model of CO2 emission from a Brazilian bare soil. Soil Biology \& Biochemistry, 32: 1459-1462.

Lloyd J, Taylor JA (1994) On the temperature dependence of soil respiration. Functional Ecology, 8, 315-323.

Lucas E, Nave ED, Vance CW, Swanston PS (2010) Curtis Harvest impacts on soil carbon storage in temperate forests. Forest Ecology and Management, 259, 857-866.

Luizao RCC, Bonde TA, Rosswall T (1992) Seasonal variation of soil microbial biomass the effects of clearfelling a tropical rainforest and establishment of pasture in the central Amazon. Soil Biology and Biochemistry, 24, 805-813

Maier CA, Albaugh TJ, Allen HL, Dougherty PM (2004) Respiratory carbon use and carbon storage in mid-rotation loblolly pine (Pinus taeda L.) plantations: the effect of site resources on the stand carbon balance. Global Change Biology, 10, 1335-1350.

Malhi Y, Baldocchi DD, Jarvis PG (1999) The carbon balance of tropical, temperate and boreal forests. Plant, Cell \& Environment, 22, 715-740.

Marañón-Jiménez S, Castro J, Kowalski AS, Serrano-Ortiz P, Reverter BR, Sánchez-Cañete EP, Zamor R (2011). Post-fire soil respiration in relation to burnt wood management in a Mediterranean mountain ecosystem. Forest Ecology and Management, 261, 14361447. 
Masyagina OV, Prokushkin SG, Koike T (2010) The influence of thinning on the ecological conditions and soil respiration in a Larch forest on Hokkaido Island. Eurasian Soil Science, 43, 693-700.

McNaughton SJ, Banyikwa FF, McNaughton MM (1998) Root biomass and productivity in a grazing ecosystem. The Serengeti. Ecology, 79(2), 587-592.

Meigs GW, Donato DC, Campbell JL, Martin JG, Law BE (2009) Forest Fire Impacts on Carbon Uptake, Storage, and Emission: The Role of Burn Severity in the Eastern Cascades, Oregon. Ecosystems, 12, 1246-1267. doi: 10.1007/s10021-009-9285-X.

Molchanov AA (1971) Productivity of organic mass in the forests of different zones. Publishing house "Nauka", Moscow.

Mukhortova L (2012) Carbon budget recovery and role of coarse woody debris in postlogging forest ecosystems of Southern Siberia. Bosque, 33(3), 261-265.

Nakane K, Tsubota H, Yamamoto M (1986) Cycling of soil carbon in a Japanese red pine forest. II. Changes occurring in the first year after a clear-felling. Ecological Research, 1, 47-58.

Nave LE, Vance ED, Swanston ChW, Curtis PS (2011) Fire effects on temperate forest soil C and N storage. Journal of Applied Ecology, 21(4), 1189-1201.

Nilsson S, Shvidenko A, Stolbovoi V, Glick M, Jonas M, Obersteiner M (2000) Full Carbon Account for Russia. Interim Rep. IR-00-021. Laxenburg, Austria. Available from: http://www.iiasa.ac.at/Publications/Documents/IR-00-021.pdf [Assessed 19 May 2012].

Nilsson S, Shvidenko A, Jonas M, McCallum I, Thompson A, Balzter H (2007) Uncertainties of a Regional Terrestrial Biota Full Carbon Account: A Systems Analysis. Water, Air, \& Soil Pollution, 7(4-5), 5-21.

Norris CE, Quideau SA, Bhatti JS, Wasylishen RE, MacKenzie MD (2009) Influence of ifre and harvest on soil organic carbon in jack pine sites. Canadian Journal of Forest Research, 39, 642-654.

NRC (2000) Ecological Indicators for the Nation. National Research Council. National Academy Press, Washington, DC.

O’Connell AM (1987) Litter decomposition, soil respiration and soil chemical and biochemical properties at three contrasting sites in karri (Eucalyptus diversicolor F. Muell.) forests of south-western Australia. Australian Journal of Ecology, 12, 31-40.

Ohashi M, Gyokusen K, Saito A (2000) Contribution of root respiration to total soil respiration in a Japanese cedar (Cryptomeria japonica D. Don) artificial forest. Ecological Research, 15(3), 323-333.

Onuchin A, Shvidenko A, Pavlov I, Schepaschenko D (2009) Russian forests: impact on Earth system . XIII World Forestry Congress. 18-25 October 2009 Buenos Aires, Argentina. Available from:

http://www.iiasa.ac.at/Research/FOR/conferences/2009/WFC/WFC09_IIASASE_abstract_Onuchin_16_10_2009_clean_final+1.pdf [assessed 12 May 2012].

Osipov AF (2011) Dynamics of organic carbon content in wet pine forests of Middle taiga. Abstract of PhD thesis, Syktyvkar, Russia.

Pan Y, Birdsey RA, Fang J, et al. (2011) A large and persistent carbon sink in the world's forests. Science, 333(6045), 988-993. doi: 10.1126/science.1201609.

Peng Y, Thomas SC (2006) Soil CO2 efflux in uneven-aged managed forests: temporal patterns following harvest and effects of edaphic heterogeneity. Plant and Soil, 289, 253-264.

Peng Y, Thomas SC, Tian D (2008) Forest management and soil respiration: Implications for carbon sequestration. Environmental Reviews, 16, 93-111. 
Popova EP, Perevozchikov VD (1996) Transformation of Lower Vegetation Layers and Litter in Pine Fillings of the Middle Angara Basin. Contemporary Problems of Ecology, 6, 47-57.

Prescott CE, Blevins LL, Staley CL (2000) Effects of clear-cutting on decomposition rates of litter and forest floor in forests of British Columbia. Canadian Journal of Forest Research, 30, 1751-1757.

Raich JW, Schlesinger WH (1992) The global carbon dioxide flux in soil respiration and its relationship to vegetation and climate. Tellus, 44 B, 81-99.

Raich JW, Tufekciogul A (2000) Vegetation and soil respiration: correlations and controls. Biogeochemistry, 48, 71-90.

Raich JW, Potter CS, Bhagawati D (2002) Interannual variability in global soil respiration, 1980-94. Global Change Biology, 8, 800-812.

Reichstein M, Rey A, Freibauer A, et al. (2003) Modeling temporal and large-scale spatial variability of soil respiration from soil water availability, temperature and vegetation productivity indices. Global Biogeochemical Cycles, 17(4), 114-1. doi: 10.1029/2003GB002035.

Rochette P, Desjardins RL, Pattey E (1991) Spatial and temporal variability of soil respiration in agricultural fields. Canadian Journal Soil Science, 71, 189-196.

Rozhkov VA, Wagner VB, Kogut BM, Konyushkov DE, Nilsson S, Sheremet VB, Shvidenko AZ (1996) Soil carbon estimates and soil carbon map for Russia. IIASA, Laxenburg, Austria.

Saynes V, Etchevers JD, Galicia L, Hidalgo C, Campo J (2012) Soil carbon dynamics in highelevation temperate forests of Oaxaca (Mexico): thinning and rainfall effects. Bosque, 33(1), 3-11. doi: 10.4067/S0717-92002012000100001.

Schepaschenko DG, Mukhortova LV, Shvidenko AZ, Vedrova EF (2013) The pool of organic carbon in the soils of Russia. Eurasian Soil Science, 46(2), 107-116.

Schepaschenko DG, Shvidenko AZ, Shalaev VS (2008) Biological productivity and carbon budget of larch forests of Northern-East Russia. Moscow. Moscow State Forest Univ.

Schepaschenko D, McCallum I, Shvidenko A, Fritz S, Kraxner F, Obersteiner M (2011) A new hybrid land cover dataset for Russia: a methodology for integrating statistics, remote sensing and in-situ information. Journal of Land Use Science, 6(4), 245-259.

Schleser GH (1982) The response of CO2 evolution from soils to global temperature changes. Zeitschr Naturforsch, 37, 287-291.

Scott-Denton LE, Sparks KL, Monson RK (2003) Spatial and temporal controls of soil respiration rate in a high-elevation, subalpine forest. Soil Biology \& Biochemistry, 35, 525-534.

Sheingauz AS (2008) Selected works. Khabarovsk, FEB RAS.

Shvidenko A, Nilsson S (2003) A synthesis of the impact of Russian forests on the global carbon budget. Tellus, 55B, 391-415.

Shvidenko A, Schepaschenko D, Nilsson S (2007) Materials for understanding of the presentday productivity of forest ecosystems of Russia. In: Basic Problems of Transition to Sustainable Forest Management in Russia (eds Sokolov V, Shvidenko A, Vtyurina O), PP 7-37, Proceedings of the International Seminar, Krasnoyarsk, Russia [in Russian]

Shvidenko A, Schepaschenko D, Nilsson S (2009) Assessment of woody detritus in forests of Russia. Forest Inventory and Planning, 1(41), 133-147 [in Russian]

Shvidenko A, Schepaschenko D, Maksyutov Sh (2010) Impact of terrestrial ecosystems of Russia on the global carbon cycle from 2003-2008: An attempt of synthesis. Proceedings of the Int. conf. on environmental observation, modeling and information systems EMVIROMIS’2010. 5-11 July 2010, Tomsk, Russia. Pp. 48-52. 
Shvidenko A, Schepaschenko D, McCallum I, Nilsson S (2010) Can the uncertainty of full carbon accounting of forest ecosystems be made acceptable to policy makers?

Climatic Change, 103(1-2), 137-157.

Shvidenko AZ, Schepaschenko DG, Vaganov EA, Sukhinin AI, Maksyutov ShSh, McCallum I, Lakyda IP (2011) Impact of Wildfire in Russia between 1998-2010 on Ecosystems and the Global Carbon Budget. Doklady Earth Science, 441(2), 1678-1682.

Shvidenko AZ, Schepaschenko DG (2014) Carbon balance of Russian forests. Siberian Forest journal, 1, in press.

Sin'kevich SM, Bakhmet ON, Ivanchikov AA (2009) Role of soils in regional carbon budget of pine forests of Karelia. Eurasian Soil Science, 42(3), 267-276.

Singh S, Amiro BD, Quideau SA (2008) Effect of forest floor organic layer and root biomass on soil respiration following boreal forest fire. Canadian Journal of Forest Research, 38, 647-655.

Six J, Jastrow JD (2002) Organic matter turnover. Encyclopedia of Soil Science. Marcel Dekker, Inc., 936-942.

Smith VR (2003) Soil respiration and its determinants on a sub-Antarctic island. Soil Biology \& Biochemistry, 35, 77-91.

Spears JDH, Holub SM, Harmon, M. E. and Lajtha, K. 2003. The influence of decomposing logs on soil biology and nutrient cycling in an old-growth mixed coniferous forest in Oregon, USA. Canadian Journal of Forest Research, 33, 2193-2211.

Stolbovoi V, McCallum I (2002) CD-ROM "Land Resources of Russia", International Institute for Applied Systems Analysis and the Russian Academy of Science, Laxenburg, Austria. Available from http://www.iiasa.ac.at/Research/FOR/russia_cd/index.htm [Assessed 19 May 2012].

Stoyan H, De-Polli H, Bohm S, Robertson GP, Paul EA (2000) Spatial heterogeneity of soil respiration and related properties at the plant scale. Plant and Soil, 222, 203-214.

Striegl RG., Wickland KP (1998) Effects of a clear-cut harvest on soil respiration in a jack pine lichen woodland. Canadian Journal of Forest Research, 28, 534.539.

Tan W, Sun L, Hu H, Chen X (2012) Effect of fire disturbances on soil respiration of Larix gmelinii Rupr. forest in the Da Xing'an Mountain during growing season. African Journal of Biotechnology, 11(21), 4833-4840.

Tarankov VI, Stepochkin LM (2005) Specifisity of carbon depositing in oak plantations of Mokhovskoe forest district of Orlovskaya oblast. Contemporary Problems of Ecology, 6, 38-43.

Tinker DB, Knight DH (2000) Coarse woody debris following fire and logging in Wyoming lodgepole pine forests. Ecosystems, 3, 472-483.

Trefilova OV (2006) Yearly carbon cycle in pine forests of middle taiga of Yenisey Siberia. Abstract of PhD thesis. Krasnoyarsk, Russia.

Vaschuk LN, Shvidenko AZ (2006) Dynamics of forests of Irkutsk region. Irkutsk.

Vedrova, E.F. 2005. Destruction processes in carbon cycle of forest ecosystems on Yenisey transect. Abstract of Doctor thesis. Krasnoyarsk, Russia.

Vedrova EF, Mukhortova LV, Ivanov VV, Krivobokov LV, Boloneva MV (2010) PostLogging Organic Matter Recovery in Forest Ecosystems of Eastern Baikal Region. The Biological Bulletin, 37(1), 69-79.

Vedrova EF, Evdokimenko MD, Bezkorovaynaya IN, Mukhortova LV, Cherednikova YuS (2012) Reserves of Carbon in the Organic Matter of Postfire Pine Forests in the Southwest of the Baikal Region. Contemporary Problems of Ecol. 5(7), 645-653.

Wang W, Feng J, Oikawa T (2009) Contribution of Root and Microbial Respiration to Soil CO2 Efflux and Their Environmental Controls in a Humid Temperate Grassland of Japan. Pedosphere, 19(1), 31-39. 
Wang W, Guo JX, Feng J, Oikawa T (2006) Contribution of root respiration to total soil respiration in a Leymus chinensis (Trin.) Tzvel. grassland of Northeast China. Journal of Integrative Plant Biology, 48(4), 409-414.

Wirth C, Schulze ED, Luhker B, et al. (2002) Forest and site type effects on the long-term carbon and nitrogen balance in pristine Scots pine forests. Plant and Soil, 242, 41-63.

Watson R, Noble I, Bolin B and 32 co-authors (2000) Summary for policymakers: land-use, landuse change and forestry. In: A special report of the Intergovernmental Panel on Climate Change. Cambridge University Press.

Xu M, Qi Y (2001) Soil-surface CO2 efflux and its spatial and temporal variations in a young ponderosa pine plantation in northern California. Global Change Biology, 7, 667-677.

Yevdokimov IV, Larionova AA, Schmitt M, Lopes de Gerenyu VO, Bahn M (2010) Experimental assessment of the contribution of plant root respiration to the emission of carbon dioxide from the soil. Eurasian Soil Science, 43(12), 1373-1381.

Zamolodchikov DG, Utkin AI, Korovin GN, Chestnykh OV (2005) Dynamics of carbon pools and fluxes on the territory of forest fund of Russia. Ecologia, 5, 323-333. 